\title{
Cyprinodontiform fishes of El Salvador
}

\author{
Francisco S. Álvarez ${ }^{1,2}$ (D), Saúl González-Murcia ${ }^{1,2,3}$ (D) Caleb D. McMahan ${ }^{4}$ (D) Wilfredo A. Matamoros ${ }^{5}$
}

1. UDP Ciencias Neotropicales, Departamento de Investigación, San Salvador, El Salvador.

2. Fundación Naturaleza El Salvador, Departamento de Investigación, San Salvador, El Salvador; samuel_biologo@hotmail.com

3. James Cook University, School of Marine and Tropical Biology, Queensland, 4811, Australia; saulogm_5@yahoo.com

4. Field Museum of Natural History, 1400 S. Lake Shore Drive, Chicago, Illinois 60605, United States of America; cmcmahan@fieldmuseum.org

5. Instituto de Ciencias Biológicas, Universidad de Ciencias y Artes de Chiapas, Libramiento Norte Poniente 1150, Colonia Lajas Maciel, CP 29039, Tuxtla Gutiérrez, Chiapas, México; wilmatamoros@yahoo.com

Recibido 17-IX-2020 • Corregido 04-XII-2020 • Aceptado 07-XII-2020

DOI: https://doi.org/10.22458/urj.v13i1.3303

\begin{abstract}
Introduction: The Cyprinodontiformes are a group of secondary freshwater fishes widely distributed in El Salvador. Currently, many species of this group are usually incorrectly identified for lack of adequate tools. Additionally, their taxonomy and distribution have changed in recent years. Objective: To provide updated information about the taxonomy and distribution of EI Salvador Cyprinodontiformes through identification keys, distribution notes, and general descriptions for all species. Methods: We carried out an extensive review of the literature, electronic databases, and museum specimens to generate a list of valid species present in El Salvador. Results: Eleven species in three families are confirmed: Profundulidae (two species), Anablepidae (one species), and Poeciliidae (eight species). We also include distribution data, both vertical and by main basins, and an illustrated guide. Conclusions: There are 11 species of Cyprinodontiformes in El Salvador and they can be found and identified with this article.
\end{abstract}

Keywords: Profundulidae, Anablepidae, Poeciliidae, America Central, distribution, taxonomic key.
RESUMEN. "Peces Ciprinodontiformes de El Salvador". Introducción: Los ciprinodontiformes son un grupo de peces secundarios de agua dulce ampliamente distribuidos en El Salvador. Actualmente hay errores de identificación por falta de herramientas adecuadas; además, su taxonomía y distribución han cambiado en los últimos años. Objetivo: Proporcionar información actualizada sobre la taxonomía y distribución de los Ciprinodontiformes de El Salvador a través de claves de identificación, notas de distribución y descripciones generales para todas las especies. Métodos: Realizamos una revisión extensa de la literatura, bases de datos electrónicas y especímenes de museo para generar una lista de especies válidas presentes en El Salvador. Resultados: Se confirman once especies en tres familias: Profundulidae (dos especies), Anablepidae (una especie) y Poeciliidae (ocho especies). También incluimos datos de distribución, tanto vertical como por cuencas principales, y una guía ilustrada. Conclusiones: Existen 11 especies de Cyprinodontiformes en El Salvador y se pueden encontrar e identificar con este artículo.

Palabras clave: Profundulidae, Anablepidae, Poeciliidae, Centro América, distribución, clave taxonómica.

The Cyprinodontiformes are a diverse group of teleost fishes distributed in temperate, subtropical and tropical, areas of the world; they are common in freshwater systems, but they also occur in brackish and marine waters (Parenti, 1981; Nelson, Grande, \& Wilson, 2016). In Asia the Cyprinodontiformes are in Madagascar, Seychelles, India, Sri Lanka, the Indo-Malaysian archipelago, and Java; in Africa around the Mediterranean Sea and from south of the Sahara Desert to South Africa and Madagascar; in Europe, Cyprinodontiformes occur mainly around the Mediterranean Sea, southeastern Spain, Italy, western Greece, and Turkey. In America from southeastern Canada south to Argentina, including the West Indies archipelago (Nelson et al., 2016). These fishes are commonly known as killifishes, topminnows, four-eyed fishes, or toothcarps (Parenti, 1981; Nelson et al., 2004) and are represented by 2,000 valid species, distributed in 14 families (Fricke, Eschmeyer, \& van der 
Laan, 2020). Cyprinodontiformes are secondary freshwater fishes, and some members can tolerate waters with elevated salinity levels, occasionally using coastal and marine waters for dispersal (Miller, 1966).

Biogeographical patterns of Cyprinodontiformes are complex, especially in Central America, where it has been largely debated (e.g. Miller, 1966; Myers, 1966; Rosen, 1975; Briggs, 1984; Bussing, 1985; Iturralde-Vinent \& MacPhee, 1999; Iturralde-Vinent, 2006; Hrbek, Seckinger, \& Meyer, 2007; Alda, Reina, Doadrio, \& Bermingham, 2013; Bagley et al., 2015; Ho, Pruett, \& Lin, 2016; Palacios, Voelker, Rodriguez, Mateos, \& Tobler, 2016; Amorim \& Costa, 2018). In this regard, the evidence provided by several authors (Myers, 1966; Rosen, 1975; Iturralde-Vinent \& MacPhee, 1999; Hrbek et al., 2007; Matamoros, McMahan, Chakrabarty, Albert, \& Schaefer, 2015) suggests that Cyprinodontiforms arrived to Nuclear Central America possibly in three dispersal events. The first event is related to ancestral land bridges that connected Northern South America and Northern Central America in the Lower Cretaceous. The second event through the ephemeral GAARlandia Bridge (Iturralde-Vinent \& MacPhee, 1999), and the third event linked to the final closing of the Panamanian isthmus (Bacon et al., 2015). Therefore, Central America harbors unique fish communities where the Cyprinodontiformes stand as one of the most relevant groups in both abundance and species richness (Miller, 1966; Matamoros et al., 2015). Indeed, Cyprinodontiforms account for $10 \%$ to $20 \%$ of the freshwater fish species in the region, a proportion that is even higher if peripheral fishes are excluded (e.g. Matamoros, Schaefer, \& Kreiser, 2009; Angulo, GaritaAlvarado, Bussing, \& López, 2013; McMahan et al., 2013).

In general, the information on the Cyprinodontiforms of El Salvador is relatively scarce, however, some regional studies include in their analyses distributional data and museum specimens collected in the country (e.g. Miller, 1966; Parenti, 1981; Ghedotti, 2000; Hrbek et al., 2007; Matamoros, Kreiser, \& Schaefer, 2012; Morales-Cazan \& Albert, 2012; Alda et al., 2013; Palacios et al., 2013; Bagley et al., 2015; Matamoros et al., 2015; Ho et al., 2016; Palacios et al., 2016; Reznick, Furness, Meredith, \& Springer, 2017; Amorim \& Costa, 2018). Even some specimens have been used as holotypes for species descriptions (e.g. Gill, 1861; Poeser, 1995). These studies provide evidence about biogeographical patterns, morphological traits, and genetic features within and between populations of Cyprinodontiforms in the region. One of the first papers on freshwater fishes of El Salvador was published approximately one hundred years ago (e.g. Hildebrand, 1925), followed by publications over the last decades which provide basic and limited information about taxonomy and distribution (e.g. Burns \& Flores, 1981; Phillips, 1981; Burns \& Ramirez, 1990; McMahan et al., 2013; Álvarez, Matamoros, \& Chicas, 2017; González-Murcia \& Álvarez, 2018; González-Murcia, Álvarez, Alvarado-Larios, Marín-Martínez, \& Angulo, 2019). However, the information on freshwater fishes of El Salvador is scarce and information gaps are evident.

In El Salvador, the Cyprinodontiformes represents $10 \%$ of the freshwater fish diversity (McMahan et al., 2013), and in some watersheds, such as the Acahuapa River, members of this order reach $26 \%$ of the total species richness, and $77 \%$ of the abundances of the fish assemblage (Álvarez et al., 2017). This highlights the importance of Cyprinodontiforms in Salvadorian freshwater systems. However, the absence of accurate taxonomic keys for the identification of species in El Salvador has generated identification errors and confusion regarding the delimitation of species. Moreover, in recent years important changes in the taxonomy of the group have occurred, as well as new advances in terms of the knowledge about their distributions. Thus, our objectives were a) to present updated taxonomic information on cyprinodontiform fishes from El Salvador, including their geographical distribution and habitat use, and b) to provide a photographic taxonomic key to facilitate their identification. 


\section{MATERIALS AND METHODS}

Records of cyprinodontiform fishes present in El Salvador were obtained from the scientific literature (Alda et al., 2013; Salgado-Maldonado et al., 2014), voucher specimens at the Museo de Historia Natural de El Salvador (MUHNES), the Instituto de Ciencias del Mar y Limnología, Universidad de El Salvador (ICMARES-UES), Museo Nacional de Ciencias Naturales, Madrid, Consejo Superior de Investigaciones Científicas (MNCN-CSIC) and electronic databases of the United States National Museum (USNM), University of Kansas (KU), Field Museum of Natural History (FMNH), Swedish Museum of Natural History (NRM), California Academy of Sciences (CAS), Tulane University (TU), Louisiana Museum of Natural Science (LSUMZ), and University of Michigan Ann Arbor (UMMZ) accessed via FishNet2 (http://www.fishnet2.org). The information about species composition was gathered and organized to construct a taxonomic key for the Cyprinodontiformes in El Salvador aided by the work of Poeser (1995); Bussing (2002); Miller, Minckley, and Norris (2009); Poeser (2011); Matamoros, Schaefer, Hernández, and Chakrabarty (2012) and Robertson and Van Tassell (2015). Family names are presented in evolutionary arrangement following Fricke et al. (2020) and within the families, the categories of genera and species are sorted alphabetically. English common names are included following Nelson et al. (2004), and Salvadoran Spanish common names are also included following McMahan et al. (2013). Distribution maps by species (see Digital Appendix) and photographs of each species, including both male and female for those species that present sexual dimorphism are presented. Furthermore, distributional data by species are provided. Also, some habitat use characteristics within the Salvadorean ecosystems where species occur are described, according to personal observations and available literature (e.g. Álvarez et al., 2017). Finally, unpublished, and updated data (localities) from the Museo de Historia Natural de El Salvador (MUHNES) and Instituto de Ciencias del Mar y Limnología, Universidad de El Salvador (ICMARESUES) are included.

\section{RESULTS}

A total of 604 museum records of Cyprinodontiforms from El Salvador were compiled. Some records were excluded because they were not identified to the species level, lacked specific geographical information, or their occurrence in El Salvador has not been validated. There were only 350 records with taxonomic information at the species level (Figure 1 and Table 1 Digital Appendix) representing three families, five genera, and 11 species: Profundulidae ( 2 species), Poeciliidae (8 species), and Anablepidae (one species) (Table 1). Within the family Poeciliidae, Poecilia gillii and $P$. butleri, as reported by McMahan et al. (2013), were excluded from this revision since recent molecular evidence suggests that these species do not occur in El Salvador (Alda et al., 2013; Ho et al., 2016; Palacios et al., 2016). Poecilia mexicana and $P$. nelsoni were included since these species occur in the country (Alda et al., 2013; Bagley et al., 2015; Ho et al., 2016; Palacios et al., 2016). For $P$. gillii, molecular and phylogeographic evidence suggests that this species occurs only in the southern portion of Central America in Panama (Alda et al., 2013; Bagley et al., 2015; Palacios et al., 2016). Therefore, a review of these individuals that have been identified as " $P$. gillii" is suggested. While $P$. butleri is geographically separated from its sister taxon $P$. nelsoni, the distribution of $P$. butleri is likely restricted to North of the Trans-Mexican Volcanic Belt in northern México (Palacios et al., 2016) while P. nelsoni spans south of the Trans-Mexican Volcanic Belt from Mexico to El Salvador (Ho et al., 2016; Palacios et al., 2016). Therefore, all the records of "P. butleri" were replaced by "P. nelsoni" due to the geographical separation between both sister taxa. For $P$. mexicana only valid records based on molecular analyses were used (see Alda et al., 2013). 
TABLE 1

Records of Cyprinodontiformes of the El Salvador by drainage.

\begin{tabular}{|c|c|c|c|c|c|c|c|c|c|c|c|c|c|c|c|}
\hline Specie & Records & A & B & C & D & $\mathbf{E}$ & $\mathbf{F}$ & G & H & I & J & K & Co & $\mathbf{L}$ & $\begin{array}{c}\text { Elevation } \\
\text { (masl) }\end{array}$ \\
\hline Profundulidae & 29 & & & & & & & & & & & & & & \\
\hline $\begin{array}{l}\text { Profundulus } \\
\text { guatemalensis }\end{array}$ & 8 & & $\mathrm{x}$ & $\mathrm{x}$ & & & & & & & & & & & $410-830$ \\
\hline Profundulus kreiseri & 21 & $x$ & & & & & & & & & & & & & $410-1320$ \\
\hline Poeciliidae & 278 & & & & & & & & & & & & & & \\
\hline Poecilia marcellinoi & 20 & $x$ & & & $x$ & $x$ & & & & & $\mathrm{x}$ & & & & $0-670$ \\
\hline Poecilia mexicana* & 7 & $x$ & & & & & & & & $x$ & & & & & $0-430$ \\
\hline Poecilia nelsoni* & 11 & $x$ & & $\mathrm{x}$ & & & $x$ & & & & & & & & $0-705$ \\
\hline Poecilia salvatoris & 57 & $x$ & $x$ & $\mathrm{x}$ & $x$ & $x$ & $x$ & & & & $x$ & & $x$ & & $0-950$ \\
\hline Poecilia sphenops & 72 & $x$ & $x$ & $\mathrm{x}$ & $x$ & $x$ & $\mathrm{x}$ & & $x$ & $x$ & $x$ & & $x$ & & $0-775$ \\
\hline $\begin{array}{l}\text { Poeciliopsis } \\
\text { pleurospilus }\end{array}$ & 66 & $\mathrm{x}$ & $\mathrm{x}$ & & $\mathrm{x}$ & $\mathrm{x}$ & $\mathrm{x}$ & & & $\mathrm{x}$ & $\mathrm{x}$ & & $x$ & & $0-1020$ \\
\hline $\begin{array}{l}\text { Poeciliopsis } \\
\text { turrubarensis }\end{array}$ & 36 & $x$ & & & & & & & $\mathrm{x}$ & & $\mathrm{x}$ & & & & $0-260$ \\
\hline $\begin{array}{l}\text { Pseudoxiphophorus } \\
\text { anzuetoi }\end{array}$ & 9 & $\mathrm{x}$ & & & & & & & & & & & & & $260-1140$ \\
\hline Anablepidae & 43 & & & & & & & & & & & & & & \\
\hline Anableps dowii & 43 & $x$ & & $\mathrm{x}$ & $x$ & & & $\mathrm{x}$ & $x$ & $x$ & $x$ & & & & $0-960$ \\
\hline
\end{tabular}

* Recently added to the Salvadoran fish fauna based on molecular studies (Alda et al., 2013; Ho et al., 2016; Palacios et al., 2016). Drainages: A: Río Lempa; B: Río Paz; C: Cara Sucia San Pedro; D: Río Grande de Sonsonate; E: Mandinga Comalapa; F: Río Jiboa; G: Estero de Jaltepeque; H: Bahía de Jiquilisco; I: Río Grande de San Miguel; J: Río Sirama; K: Río Goascorán; Co: Lago de Coatepeque; L: Golfo de Fonseca.

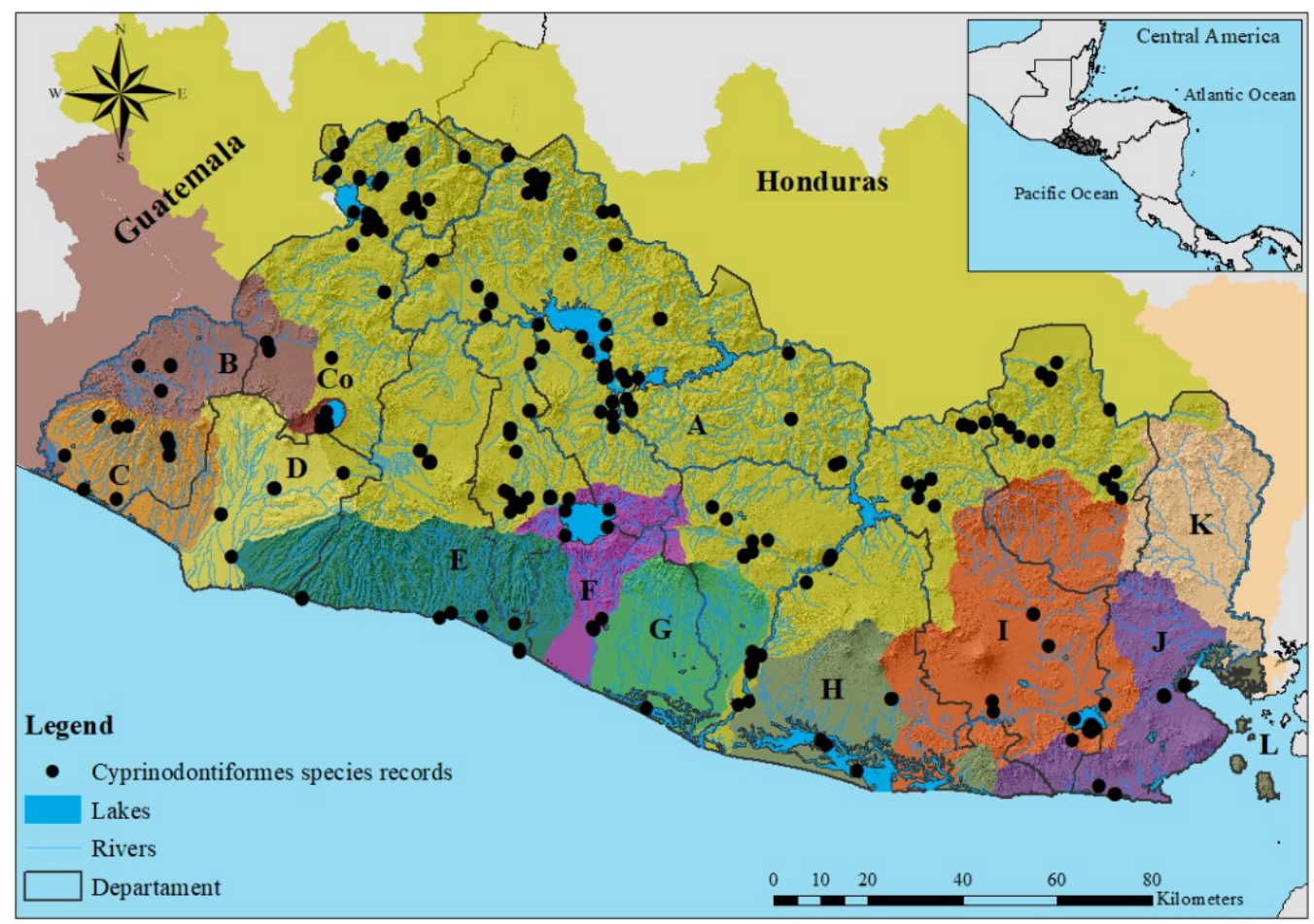

Fig. 1. Records of species of Cyprinodontiformes of El Salvador. Drainages: A: Río Lempa; B: Río Paz; C: Cara Sucia San Pedro; D: Río Grande de Sonsonate; E: Mandinga Comalapa; F: Río Jiboa; G: Estero de Jaltepeque; H: Bahía de Jiquilisco; I: Grande de San Miguel; J: Río Sirama; K: Río Goascorán; Co: Lago de Coatepeque; L: Golfo de Fonseca. 
Family Profundulidae: One of the few endemic fish families of Central America and Mexico (Morcillo, Ornelas-García, Alcaraz, Matamoros, \& Doadrio, 2016; Matamoros, Domínguez-Cisneros, Velázquez-Velázquez, \& McMahan, 2018). This family has been subject to several taxonomic reviews and changes (Morcillo et al., 2016). Previously, the only recognized genus within the family was Profundulus Hubbs 1924, however, molecular studies divided it into the genera Profundulus and Tlaloc Álvarez \& Carranza 1951 with eight and four valid species respectively (Matamoros et al., 2018; Flores, 2020; Fricke et al., 2020). In El Salvador, Profundulus is represented by two species; $P$. guatemalensis and P. kreiseri (McMahan et al., 2013), and both species occur mainly in highland areas of the country. Both species tend to inhabit little disturbed rivers and small streams, and at upper portions of basins occur in habitats characterized by rocky substrates, well-oxygenated waters, moderate to high currents, and surrounding vegetation (riparian forest).

Profundulus guatemalensis (Günther, 1866); "Guatemalan killifish", "Escamudo guatemalteco", "Olomina" (Figure 2A). Remarks: Profundulus guatemalensis has been considered a valid species since its original description by Günther (1866). Currently supported at the molecular level, the distribution of $P$. guatemalensis is restricted to the Pacific Slope of Guatemala and El Salvador (Morcillo et al., 2016) (Fig. 1 in Digital Appendix).

Profundulus kreiseri Matamoros, Schaefer, Hernández, \& Chakrabarty 2012; Olomina, Escamudo de Kreiser, Kreiser's killifish (Figure 2B). Remarks: Profundulus kreiseri was originally described based on material from the Ulúa and Chamelecón Rivers in Honduras (Matamoros, Schaefer et al., 2012). It has been reported in the Atlantic slope in Guatemala and the Pacific slope in El Salvador (McMahan et al., 2013; Morcillo et al., 2016). Its distribution in El Salvador is limited to the north region of El Salvador, in tributaries of the Río Lempa basin (Fig. 1 in Digital Appendix).

Family Poeciliidae: This family is comprised of 274 species, of which ten have been described in the last decade from Middle America (Fricke et al., 2020). The family Poeciliidae is distributed from the South of the United States to the North East of Argentina (Miller et al., 2009), and its greatest diversification occurred in Central America (Rosen \& Bailey, 1963; Miller, 1966). Biogeographic studies place the origin of this family in Central and South America (Reznick et al., 2017; Tagliacollo, Duke-Sylvester, Matamoros, Chakrabarty, \& Albert, 2017), however, the estimated dates of origin are still debated. In El Salvador three genera are present; Poeciliopsis Regan, 1913, Poecilia Bloch \& Schneider, 1801, and Pseudoxiphophorus Bleeker, 1860, with two, five, and one species respectively (McMahan et al., 2013). In general, the species of this family in El Salvador inhabit small rivers, streams, lakes, and lagoons, from clear to disturbed water, rivers and streams with little surrounding vegetation, characterized by substrate mainly composed of rocks, logs, silt, leaves, and sand, shallow waters, and moderate to low currents.

Poecilia marcellinoi Poeser, 1995; "Ilopango molly", "Chimbolo", "Bute", "Olomina", "Topote de Ilopango" (Figure 2C). Remarks: Poecilia marcellinoi belongs to the subgenus Mollienesia within the $P$. sphenops species complex (Palacios et al., 2016). The holotype was collected in Lake Ilopango, El Salvador. Poeser (1995) and Palacios et al. (2016) recognize P. marcellinoi as a valid species occurring in the Pacific slope of Guatemala, Honduras, El Salvador, and Nicaragua (Fig. 2 in Digital Appendix).

Poecilia mexicana Steindachner, 1863; "Atlantic molly", "Chimbolo", "Bute", "Olomina" (Figure 2D). Remarks: This species belongs to the subgenus Mollienesia within the $P$. mexicana species complex (Palacios et al., 2016). Poecilia mexicana was previously considered a synonym of $P$. sphenops (Rosen \& Bailey, 1963). Currently, molecular evidence supports $P$. mexicana as a valid species, distributed from central Mexico to southern Central America, including El Salvador (Alda et al., 2013; Bagley et al., 2015; Palacios et al., 2016). Its morphological plasticity hinders its identification from other congeneric species (Bagley et al., 2015). We consider that in El Salvador $P$. 
mexicana has been misidentified as P. sphenops, P. gillii, P. marcellinoi, and P. salvatoris (Fig. 2 in Digital Appendix).

Poecilia nelsoni Meek, 1904; "Pacific molly", "Chimbolo", "Bute", "Olomina", "Topote del Pacífico" (Figure 2E). Remarks: Poecilia nelsoni belongs to the subgenus Mollienesia within the $P$. mexicana species complex (Palacios et al., 2016). Described by Meek (1904) and revalidated by Poeser (2003); some authors considered it a synonym of $P$. sphenops (Rosen \& Bailey, 1963; Lucinda, 2003) or P. butleri (Schultz \& Miller, 1971; Parenti, Clayton, \& Howe, 1999). Recent molecular studies revealed that $P$. nelsoni is a sister taxon of $P$. butleri (Palacios et al., 2016) occurring south of the Trans-Mexican Volcanic Belt (Ho et al., 2016; Palacios et al., 2016) to El Salvador and potentially in Honduras. Therefore, we considered that records of $P$. butleri in El Salvador by McMahan et al. (2013) corresponds to $P$. nelsoni and its distribution must be corrected for the Nuclear Middle America region (Fig. 2 in Digital Appendix).

Poecilia salvatoris Regan, 1907; "Salvadoran molly", "Chimbolo", "Bute", "Olomina", "Topote de El Salvador" (Figure 2F). Remarks: Poecilia salvatoris belongs to the subgenus Mollienesia within the P. mexicana species complex (Palacios et al., 2016); previously considered a synonym of $P$. sphenops (Rosen \& Bailey, 1963). Poeser (1995) recognized $P$. salvatoris as a morphologically valid taxon, however, some molecular studies suggest that this species might be a morphotype of P. mexicana (Bagley et al., 2015; Ho et al., 2016), therefore, a taxonomic revision is suggested (Fig. 3 in Digital Appendix).

Poecilia sphenops Valenciennes, 1846; "Mexican molly", "Chimbolo", "Bute", "Olomina", "Topote mexicano" (Figure 2G). Remarks: Part of the subgenus Mollienesia within the P. sphenops species complex (Palacios et al., 2016), the taxonomic status of $P$. sphenops is supported by both morphological and molecular evidence (Bagley et al., 2015; Palacios et al., 2016). This species occurs south of the Trans-Mexican Volcanic Belt, from Mexico to Nicaragua (Palacios et al., 2016) (Fig. 3 in Digital Appendix).

Poeciliopsis pleurospilus (Günther, 1866); "Largespot livebearer", "Chimbolo”, "Olomina de manchas", "Bute de manchas", "Guatopote manchote" (Figure 21). Remarks: Poeciliopsis pleurospilus was previously considered as a junior synonym of $P$. gracilis (Rosen \& Bailey, 1963). Subsequently, it was recognized as a valid species (Nelson et al., 2004), occurring in Mexico, Guatemala, Honduras, El Salvador, and Nicaragua (Bussing, 2008; Miller et al., 2009) (Fig. 4 in Digital Appendix).

Poeciliopsis turrubarensis (Meek, 1912); "Barred livebearer", "Bute con rayas", "Olomina con rayas", "Chimbolo", "Guatopote del Pacífico" (Figure 2H). Remarks: Originally described by Meek (1912). Poeciliopsis turrubarensis occurs in the Pacific slope drainages south of the TransMexican Volcanic Belt in Mexico south to Colombia (Mateos, Sanjur, \& Vrijenhoek, 2002; Miller et al., 2009). In El Salvador, it is usually found in the lower basin of rivers and streams (Fig. 4 in Digital Appendix).

Pseudoxiphophorus anzuetoi Rosen \& Bailey, 1979; "Anzueto's killifish", "Bute", "Chimbolo", "Olomina" (Figure 2J). Remarks: Regan (1913) initially considered the genus Pseudoxiphophorus as a subgenus within the genus Heterandria Agassiz 1853, Rosen and Bailey (1963) placed Pseudoxiphophorus in synonymy with Heterandria, while other authors recognized Pseudoxiphophorus and Heterandria as different genera (Hubbs, 1924; Miller, 1974). Based on morphological evidence, the genus Pseudoxiphophorus was recognized as valid and Heterandria remained as a monotypic genus with its only known member $\mathrm{H}$. formosa (Morales-Cazan \& Albert, 2012). Recently, all Middle American species of the genus Heterandria were reassigned to the genus Pseudoxiphophorus (Morales-Cazan \& Albert, 2012). McMahan et al. (2013) recognized this listed species as $H$. anzuetoi, and we update its record as $P$. anzuetoi. This species occurs in El Salvador, 
Guatemala, and Honduras (Fricke et al., 2020). It is usually found in rivers and streams near Cerrón Grande damming in the middle basin of the Río Lempa (Fig. 5 in Digital Appendix).

Family Anablepidae: This family is represented by a total of 19 species distributed in the Neotropics from Mexico to South America (Fricke et al., 2020). The origin of the family is still debated, with some studies suggesting that the clade originated in the Lower Cretaceous (130-110 Ma), before Africa and South America split (Rosen, 1975; Ghedotti, 2000; Hrbek et al., 2007) or between the Upper Cretaceous and the Early Palaeocene (62-67 Ma) (Reznick et al., 2017). Recent molecular studies suggest that Anablepidae originated in South America during the Oligocene ( 29.6 Ma) (Amorim \& Costa, 2018), followed by a separation between the oviparous brackish and marine genus Oxyzygonectes Fowler 1916 and the clade comprised by the viviparous anablepids including the brackish and marine genus Anableps Scopoli 1777 and the predominantly freshwater genus Jenynsia Günther 1866 (27.9 Ma), which eventually diverged from each other in the Miocene (12.5 $\mathrm{Ma})$.

Anableps dowii Gill, 1861; "Pacific four-eyed fish", "Cuatro Ojos" (Figure 2K). Remarks: The holotype of this species was collected in the Bay of La Unión, El Salvador (Gill, 1861). Its distribution range includes Mexico, Guatemala, El Salvador, Honduras, and Nicaragua. It occurs in freshwater, brackish, and marine environments. In El Salvador, $A$. dowii occurs in many watersheds at an elevation ranging from 0 to 960 masl (Fig. 6 in Digital Appendix). Anableps dowii inhabits coastal lagoons, estuaries, rivers with moderate to low currents. It is usually found in deep waters and wide rivers, substrates mainly composed of sand, silt, and rocks, in open environments with little surrounding vegetation, it is common to observe it on the surface of the rivers.

\section{Key to the Salvadoran species of the Order Cyprinodontiformes:}

1a. Head wide and depressed; eyes raised above the top of the head and divided longitudinally, producing two pupils in each eye (Anablepidae; Anableps) A. dowii 1b. Head small and rounded; eyes not elevated on top of the head and not producing two pupils in each eye; eyes on sides of body...

2a. Humeral spot present; males without gonopodium; dorsal and anal fins posterior to the transverse half-line of the body; mouth terminal; lower jaw usually longer than the upper jaw (Profundulidae; Profundulus).

2 b. Humeral spot absent; males with gonopodium; dorsal and anal fins anterior or located above of the transverse half-line of the body; mouth superior; jaws of the same size (Poeciliidae).

3a. Oval milky spots on the sides of the body (different from the dark brown spots typical of $P$. punctatus); preorbital nearly covered with well-developed scales; scales in the caudal fin covering the anterior, up to the middle, portion of the fin; 19-23 caudal-fin rays (very rarely 18 or 24); 17-20 pectoral-fin rays (very rarely 16 or 21 )... P. guatemalensis

$3 \mathrm{~b}$. Oval milky spots on the sides of the body absent or not conspicuous; the preorbital region with at least three to four conspicuous scales (not deeply embedded under the skin); scales in the caudal fin that covering only the anterior portion of the fin, not reaching their middle portion; caudal fin with 13-18 rays, pectoral fin with13-16 rays. P. kreiseri

4a. Reticulated pattern on the body very prominent; the origin of the dorsal fin of the females is located behind the origin of the anal fin; gonopodium long which extends almost to the end of the dorsal fin or nearly to the base of the caudal peduncle; pelvic fins not modified in males. 5 
4b. Reticulated pattern on the body weak; the origin of the dorsal fin of the females commonly above the origin of the anal fin; gonopodium short, rarely reaches half of the dorsal fin; modified pelvic fins in adult males, the tip of the first ray with a soft swelling, second ray thickened (Poecilia)...

5a. Reticulated pattern formed by the scales on the body very prominent (defined dots or vertical bars present); gonopodium rays folded, and thin; without dark pigment at the end of the peduncle (Poeciliopsis)....

$5 b$. Reticulated pattern formed by the scales on the body very prominent (dark reticulated network); gonopodium rays unfolded, ray tip of sickle-shaped gonopodium; dark pigment at the end of the peduncle present (Pseudoxiphophorus).

P. anzuetoi

6a. Lateral marks forming 6-9 vertical lines.

P. turrubarensis

6b. Lateral marks forming dark spots (usually present) greater than the diameter of the pupil P. pleurospilus

7a. Inner jaw dentition unicuspid ...8

7b. Inner jaw dentition tricuspid. 10

8a. 18 scales around caudal peduncle. P. mexicana

8 b. 16 scales around caudal peduncle .9

9a. 9 anal-fin rays; dorsal fin reddish with a black spot on its base (sometimes the size of the entire fin) P. salvatoris

9b. 8 anal-fin rays; dorsal and anal fins light yellow. P. nelsoni 10a. 18 scales around caudal peduncle; dorsal and caudal fins with dark spots (pigmented spots), both fins yellow or soft orange. P. sphenops 10b. 16 scales around caudal peduncle; dorsal and caudal fins without black spots, both fins reddish to dark orange; a blotch at the caudal-fin base on scales of caudal-peduncle present.. P. marcellinoi 
A

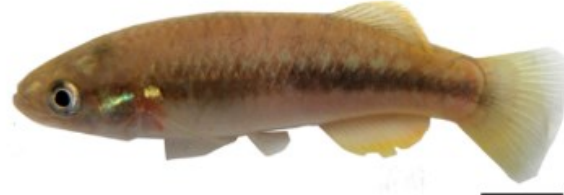

C

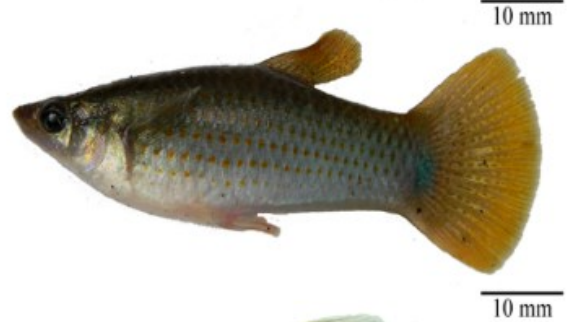

E
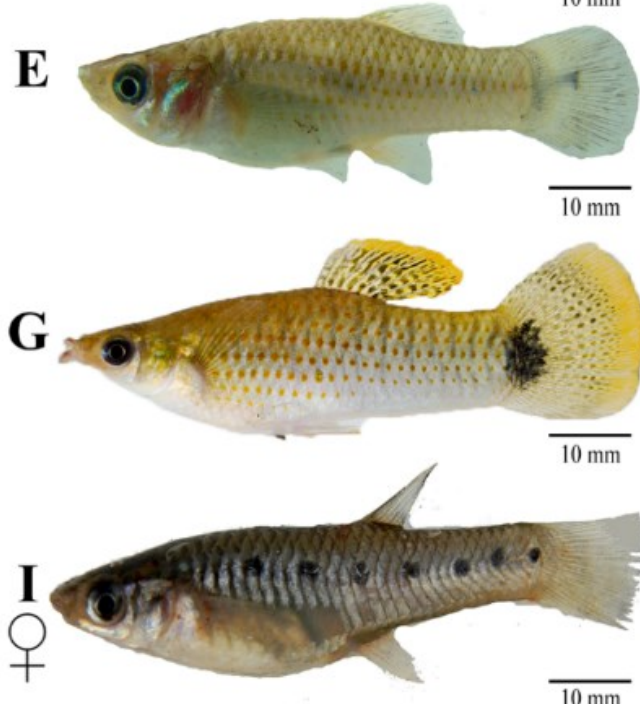

$10 \mathrm{~mm}$
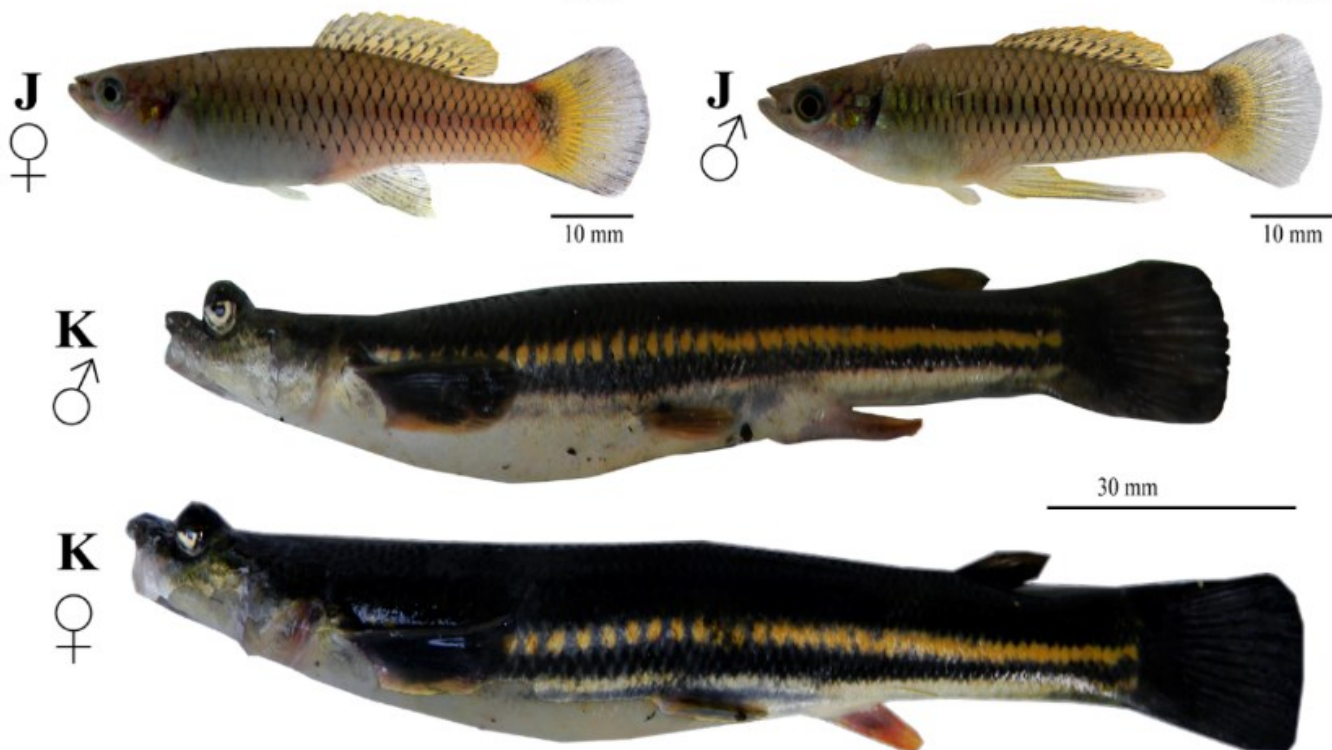

Fig. 2. Cyprinodontiformes fishes of El Salvador: A. Profundulus guatemalensis, B. Profundulus kreiseri, C. Poecilia marcellinoi, D. Poecilia mexicana, E. Poecilia nelsoni, F. Poecilia salvatoris, G. Poecilia sphenops, H. Poeciliopsis turrubarensis, I. Poeciliopsis pleurospilus (male and female), J. Pseudoxiphophorus anzuetoi (male and female), K. Anableps dowii (male and female). 


\section{DISCUSSION}

Members of the Cyprinodontiformes are among the most conspicuous fishes in Salvadorian rivers. Some species have very restricted ranges in the country, such as $P$. guatemalenis, $P$. kreiseri, and $P$. anzuetoi. For instance, $P$. kreiseri occurs in the north side of the country on the border with Honduras and Guatemala in the Río Lempa basin, while $P$. guatemalensis occurs in the northwest side of the country near the border with Guatemala in the Río Paz and Cara Sucia San Pedro basin. Both inhabit mountain rivers, whereas the distribution of $P$. anzuetoi appears to be restricted to the middle reaches of the Río Lempa basin, near to Cerrón Grande dam. The rest of the members of the Poeciliidae family and $A$. dowii are widely distributed in almost all the watersheds of El Salvador. The distribution of $A$. dowii in freshwater systems in El Salvador is unusual when compared to other countries where this species occurs close to the coasts (Miller et al., 2009; Robertson \& Van Tassell, 2015), although there are records at 670 masl in Honduras (Miller, 1979), while in El Salvador this species is found at altitudes above 900 masl.

Within the genus Poecilia, several important taxonomic modifications had occurred that affect the species composition for El Salvador. In this review, five species of the genus Poecilia are considered for El Salvador, which can be differentiated morphologically based on aspects of traditional taxonomy and that is supported by molecular studies. For example, previously $P$. gillii was considered to be distributed in almost all Central American countries (e.g. Bussing, 2002; Matamoros et al., 2009), however, molecular phylogeographic and systematic work, revealed that the distribution of $P$. gillii is restricted to Panama, excluding its occurrence in El Salvador (Alda et al., 2013; Bagley et al., 2015; Ho et al., 2016; Palacios et al., 2016). While other molecular studies concluded that $P$. mexicana is widely distributed in Central Mexico up to Panama on the Pacific and Atlantic slopes (Alda et al., 2013; Bagley et al., 2015; Ho et al., 2016; Palacios et al., 2016). Also, P. nelsoni was separated from $P$. butleri limiting its distribution north of the Trans-Mexican Volcanic Belt to Sonora, and $P$. nelsoni from South of the Trans-Mexican Volcanic Belt to El Salvador (Ho et al., 2016; Palacios et al., 2016). However, we recognize $P$. salvatoris as a morphologically valid species, despite a recent molecular study claims that this taxon could represent a morphotype of $P$. mexicana and that a review is needed (Bagley et al., 2015; Ho et al., 2016).

It is evident that this group is complex and diverse, and still genetic and morphological studies are necessary for clarifying the taxonomy of some species of this group (mainly of Poecilia genus) for the Mesoamerican region. This research compiled the most recent changes and relevant findings on the taxonomy, systematics, distribution, and habitat use of the Cyprinodontiformes in El Salvador. We recognize that there are still gaps in information and additional studies are necessary to improve our understanding of the freshwater fishes of the country. We hope that this document serves as a tool that facilitates the correct identification of the species both in the field and laboratory for future research.

\section{ACKNOWLEDGEMENTS}

The authors thank R. Alvarado Larios from the Museo de Historia Natural de El Salvador (MUHNES) for providing valuable information about the fish collection. We also appreciate the support of Leonel Méndez Gutiérrez in the production of maps. We are thankful to Michi Tobler for providing photographs (Poecilia sphenops) for the illustration of this document. 


\section{ETHICAL, CONFLICT OF INTEREST AND FINANCIAL STATEMENTS}

The authors declare that they have complied with all pertinent ethical and legal requirements, both during the study and in the production of the manuscript; that there are no conflicts of interest of any kind; that all financial sources are clearly stated in the acknowledgments section; and that they agree with the final edited version of the article. A signed document has been filed in the journal archives.

The declaration of the contribution of each author to the manuscript is as follows: F.S.A.: Conception of the idea, F.S.A, and W.A.M.: conceptualization, F.S.A., and S.G.M.: data collection, F.S.A., S.G.M., and W.A.M.: data curation, F.S.A., S.G.M., C.D.M., and W.A.M.: data analysis, F.S.A., S.G.M., C.D.M., and W.A.M.: writing and editing of the manuscript.

\section{REFERENCES}

Alda, F., Reina, R. G., Doadrio, I., \& Bermingham, E. (2013). Phylogeny and biogeography of the Poecilia sphenops species complex (Actinopterygii, Poeciliidae) in Central America. Molecular Phylogenetics and Evolution, 66(3), 10111026. DOI: 10.1016/j.ympev.2012.12.012

Álvarez, F. S., Matamoros, W. A., \& Chicas, F. A. (2017). The contribution of environmental factors to fish assemblages in the Río Acahuapa, a small drainage in Central America. Neotropical Ichthyology, 15(3), e170023. DOI: 10.1590/1982-0224-20170023

Amorim, P. F., \& Costa, W. J. (2018). Multigene phylogeny supports diversification of four-eyed fishes and one-sided livebearers (Cyprinodontiformes: Anablepidae) related to major South American geological events. PloS One, 13(6), e0199201. DOI: 10.1371/journal.pone.0199201

Angulo, A., Garita-Alvarado, C. A., Bussing, W. A., \& López, M. I. (2013). Annotated checklist of the freshwater fishes of continental and insular Costa Rica: additions and nomenclatural revisions. Check List, 9(5), 987-1019. DOI: 10.15560/9.5.987

Bacon, C. D., Silvestro, D., Jaramillo, C., Smith, B. T., Chakrabarty, P., \& Antonelli, A. (2015). Biological evidence supports an early and complex emergence of the Isthmus of Panama. Proceedings of the National Academy of Sciences, 112(19), 6110-6115. DOI: 10.1073/pnas.1423853112

Bagley, J. C., Alda, F., Breitman, M. F., Bermingham, E., van den Berghe, E. P., \& Johnson, J. B. (2015). Assessing species boundaries using multilocus species delimitation in a morphologically conserved group of neotropical freshwater fishes, the Poecilia sphenops species complex (Poeciliidae). PloS One, 10(4), e0121139. DOI: 10.1371/journal.pone.0121139

Briggs, J. C. (1984). Freshwater fishes and biogeography of Central America and the Antilles. Systematic Zoology, 33(4), 428-435.

Burns, J. R., \& Ramirez, M. A. (1990). Annual pattern of reproduction of the bagre, Arius guatemalensis (Pisces: Ariidae), in El Salvador. Revista de Biología Tropical, 38(2), 487-490.

Burns, J. R., \& Flores, J. A. (1981). Reproductive biology of the cuatro ojos, Anableps dowi (Pisces: Anablepidae), from El Salvador and its seasonal variations. Copeia, (1), 25-32.

Bussing, W. A. (1985). Patterns of distribution of the Central American ichthyofauna. In F. Stehli \& S. Webb (Eds.). The great American biotic interchange (pp. 453-473). Boston, MA: Springer.

Bussing, W. A. (2002). Peces de las aguas continentales de Costa Rica. San José, Costa Rica: Universidad de Costa Rica.

Bussing, W. A. (2008). A new species of poeciliid fish, Poeciliopsis santaelena, from Peninsula Santa Elena, Area de Conservación Guanacaste, Costa Rica. Revista de Biología Tropical, 56(2), 829-838. 
Flores, L. F. D. M. (2020). Profundulus chimalapensis, una nueva especie de pez ciprinodóntido (Cyprinodontiformes: Profundulidae) del Río Coatzacoalcos, México. Revista de Biología Tropical, 68(4). DOI: 10.15517/RBT.V68I4.40340

Fricke, R., Eschmeyer, W., \& van der Laan, R. (2020). Eschmeyer's Catalog of Fishes: Genera, Species, References. Retrieved from http://researcharchive.calacademy.org/research/ichthyology/catalog/fishcatmain.asp

Ghedotti, M. (2000). Phylogenetic analysis and taxonomy of the poecilioid fishes (Teleostei: Cyprinodontiformes). Zoological Journal of the Linnean Society, 130(1), 1-53. DOI: 10.1111/j.1096-3642.2000.tb02194.x

Gill, T. (1861). Description of a new species of the genus Anableps of Gronovius. Proceedings of the Academy of Natural Sciences of Philadelphia, 13, 3-6.

González-Murcia, S., \& Álvarez, F. S. (2018). Your place, my place..., distribution of Agonostomus monticola and Sicydium multipunctatum in the Acahuapa Watershed. Revista Mexicana de Biodiversidad, 89(3), 854-864. DOI: 10.22201/ib.20078706e.2018.3.2244

González-Murcia, S., Álvarez, F. S., Alvarado-Larios, R., Marín-Martínez, C. M., \& Angulo, A. (2019). The ichthyology collection at the Natural History Museum of El Salvador (MUHNES): Species checklist and new country records. Zootaxa, 4559(2), 281-313.DOI: 10.11646/zootaxa.4559.2.4

Hildebrand, S. F. (1925). Fishes of the Republic of El Salvador Central America. Bulletin of the Bureau of Fisheries, 41, 237287.

Ho, A. L., Pruett, C. L., \& Lin, J. (2016). Phylogeny and biogeography of Poecilia (Cyprinodontiformes: Poeciliinae) across Central and South America based on mitochondrial and nuclear DNA markers. Molecular Phylogenetics and Evolution, 101, 32-45. DOI: 10.1016/j.ympev.2016.04.032

Hrbek, T., Seckinger, J., \& Meyer, A. (2007). A phylogenetic and biogeographic perspective on the evolution of poeciliid fishes. Molecular Phylogenetics and Evolution, 43(3), 986-998. DOI: 10.1016/j.ympev.2006.06.009

Hubbs, C. L. (1924). Studies of the fishes of the order Cyprinodontes. Miscellaneous Publications of the Museum of Zoology, University of Michigan, 16, 1-86.

Iturralde-Vinent, M., \& MacPhee, R. D. (1999). Paleogeography of the Caribbean region: implications for Cenozoic biogeography. Bulletin of the American Museum of Natural History, (238), 1-95.

Iturralde-Vinent, M. (2006). Meso-Cenozoic Caribbean paleogeography: implications for the historical biogeography of the region. International Geology Review, 48(9), 791-827. DOI: 10.2747/0020-6814.48.9.791

Lucinda, P. H. (2003). Family Poeciliidae. In R. E. Reis, S. O. Kullander, \& C. J. Ferraris (Eds.), Check list of the freshwater fishes of South and Central America (pp. 555-581). Porto, Alegre: EDIPUCRS.

Matamoros, W. A., Schaefer, J. F., \& Kreiser, B. R. (2009). Annotated checklist of the freshwater fishes of continental and insular Honduras. Zootaxa, 2307(1), 1-38. DOI: 10.11646/zootaxa.2307.1.1

Matamoros, W. A., Kreiser, B. R., \& Schaefer, J. F. (2012). A delineation of Nuclear Middle America biogeographical provinces based on river basin faunistic similarities. Reviews in Fish Biology and Fisheries, 22(1), 351-365. DOI: $10.1007 / \mathrm{s} 11160-011-9232-8$

Matamoros, W. A., Schaefer, J. F., Hernández, C. L., \& Chakrabarty, P. (2012). Profundulus kreiseri, a new species of Profundulidae (Teleostei, Cyprinodontiformes) from northwestern Honduras. ZooKeys, 227(227), 49-62. DOI: 10.3897/zookeys.227.3151

Matamoros, W. A., McMahan, C. D., Chakrabarty, P., Albert, J. S., \& Schaefer, J. F. (2015). Derivation of the freshwater fish fauna of Central America revisited: Myers's hypothesis in the twenty-first century. Cladistics, 31(2), 177-188. DOI: $10.1111 /$ cla.12081 
Matamoros, W. A., Domínguez-Cisneros, S. E., Velázquez-Velázquez, E., \& McMahan, C. D. (2018). Description of a New Species of Killifish of the Genus Profundulus (Atherinomorpha: Profundulidae) from the Mexican State of Oaxaca. Copeia, 106(2), 239-246. DOI: 10.1643/Cl-17-677

Mateos, M., Sanjur, O. I., \& Vrijenhoek, R. C. (2002). Historical biogeography of the livebearing fish genus Poeciliopsis (Poeciliidae: Cyprinodontiformes). Evolution, 56(5), 972-984. DOI: 10.1111/j.0014-3820.2002.tb01409.x

McMahan, C. D., Matamoros, W. A., Álvarez, F. S., Henríquez, W. Y., Recinos, H. M., Chakrabarty, P., ... Herrera, N. (2013). Checklist of the inland fishes of El Salvador. Zootaxa, 3608(6), 440-456. DOI: 10.11646/zootaxa.3608.6.2

Meek, S. E. (1904). The fresh-water fishes of Mexico north of the Isthmus of Tehuantepec (Vol. 5). Chicago: Field Columbian Museum.

Meek, S. E. (1912). New species of fishes from Costa Rica. Nuevas species de peces de Costa Rica. Fieldiana Zoology, 10(7), 69-75.

Miller, R. R. (1966). Geographical distribution of Central American freshwater fishes. Copeia, (4), 773-802.

Miller, R. (1974). Mexican species of the genus Heterandria, subgenus Pseudoxiphophorus (Pisces: Poeciliidae). Transactions of the San Diego Society of Natural History, 17, 235-250. DOI: 10.5962/bhl.part.19967

Miller, R. R. (1979). Ecology, habits and relationships of the middle american cuatro ojos, Anableps dowi (pisces: Anablepidae). Copeia, 1979(1), 82-91.

Miller, R. R., Minckley, W., \& Norris, S. M. (2009). Peces dulceacuícolas de México. México: Comisión Nacional para el Conocimiento y Uso de la Biodiversidad. Sociedad ictiológica Mexicana A C. El Colegio de la Frontera Sur, México. Consejo de los Peces del Desierto, México-Estados Unidos.

Morales-Cazan, A., \& Albert, J. S. (2012). Monophyly of Heterandriini (Teleostei: Poeciliidae) revisited: a critical review of the data. Neotropical Ichthyology, 10(1), 19-44. DOI: 10.1590/S1679-62252012000100003

Morcillo, F., Ornelas-García, C. P., Alcaraz, L., Matamoros, W. A., \& Doadrio, I. (2016). Phylogenetic relationships and evolutionary history of the Mesoamerican endemic freshwater fish family Profundulidae (Cyprinodontiformes: Actinopterygii). Molecular Phylogenetics and Evolution, 94, 242-251. DOI: 10.1016/j.ympev.2015.09.002

Myers, G. S. (1966). Derivation of the freshwater fish fauna of Central America. Copeia, (4), 766-773.

Nelson, J. S., Crossman, E. J., Espinosa-Perez, H., Findley, L. T., Gilbert, C. R., Lea, R. N., \& Williams, J. D. (2004). Common and scientific names of fishes from the United States, Canada and Mexico. Bethesda, United States: American Fisheries Society.

Nelson, J. S., Grande, T. C., \& Wilson, M. V. (2016). Fishes of the World. New Jersey: John Wiley \& Sons.

Palacios, M., Arias-Rodriguez, L., Plath, M., Eifert, C., Lerp, H., Lamboj, A., . . Tobler, M. (2013). The rediscovery of a long described species reveals additional complexity in speciation patterns of poeciliid fishes in sulfide springs. PloS One, 8(8), e71069. DOI: 10.1371/journal.pone.0071069

Palacios, M., Voelker, G., Rodriguez, L. A., Mateos, M., \& Tobler, M. (2016). Phylogenetic analyses of the subgenus Mollienesia (Poecilia, Poeciliidae, Teleostei) reveal taxonomic inconsistencies, cryptic biodiversity, and spatiotemporal aspects of diversification in Middle America. Molecular Phylogenetics and Evolution, 103, 230-244. DOI: 10.1016/j.ympev.2016.07.025

Parenti, L. R. (1981). A phylogenetic and biogeographic analysis of cyprinodontiform fishes (Teleostei, Atherinomorpha). Bulletin of the American Museum of Natural History, 168(4), 335-557.

Parenti, L. R., Clayton, J. M., \& Howe, J. C. (1999). Catalog of Type Specimens of Recent Fishes in the National Museum of Natural History, Smithsonian Institution, 9: Family Poeciliidae (Teleostei: Cyprinodontiformes). Smithsonian Institution Press, 604, 1-32. 
Phillips, P. C. (1981). Annotated Checklist of Fishes at Jiquilisco Bay, El Salvador. Revista de Biología Tropical, 29(1), 45-58.

Poeser, F. N. (1995). Nonrandom variation in Poecilia marcellinoi n. sp. and P. salvatoris Regan, 1907 in El Salvador (Pisces, Poeciliidae). Bijdragen tot de Dierkunde, 64(4), 239-252.

Poeser, F. N. (2003). From the Amazon river to the Amazon molly and back again.(PhD Thesis). IBED, Amsterdam University, Amsterdam, NL. Retrieved from https://hdl.handle.net/11245/1.211684

Poeser, F. N. (2011). A new species of Poecilia from Honduras (Teleostei: Poeciliidae). Copeia, (3), 418-422. DOI: $10.1643 / \mathrm{Cl}-09-111$

Regan, C. T. (1913). A Revision of the Cyprinodont Fishes of tho Subfamily Pœciliinæ. Proceedings of the Zoological Society of London, 5(83), 977-1018.

Reznick, D. N., Furness, A. I., Meredith, R. W., \& Springer, M. S. (2017). The origin and biogeographic diversification of fishes in the family Poeciliidae. PloS One, 12(3), e0172546. DOI: 10.1371/journal.pone.0172546

Robertson, D., \& Van Tassell, J. (2015). Shorefishes of the Greater Caribbean: online information system. Smithsonian Tropical Research Institute. Retrieved from https://biogeodb.stri.si.edu/sftep/en/thefishes/species/17

Rosen, D. E., \& Bailey, R. M. (1963). The poeciliid fishes (Cyprinodontiformes): their structure, zoogeography, and systematics. Bulletin of the American Museum of Natural History, 126(1), 1-76.

Rosen, D. E. (1975). A vicariance model of Caribbean biogeography. Systematic Biology, 24(4), 431-464. DOI: $10.2307 / 2412905$

Salgado-Maldonado, G., Matamoros, W. A., Caspeta-Mandujano, J. M., Martínez-Ramírez, E., Mendoza-Franco, E. F., \& Velázquez-Velázquez, E. (2014). Range extension of helminth parasites of Profundulus spp.(Teleostei: Profundulidae) from southern Mexico and Central America. Check List, 10(6), 1507-1513. DOI: 10.15560/10.6.1507

Schultz, R. J., \& Miller, R. R. (1971). Species of the Poecilia sphenops complex (Pisces: Poeciliidae) in Mexico. Copeia, (2), 282-290.

Tagliacollo, V. A., Duke-Sylvester, S. M., Matamoros, W. A., Chakrabarty, P., \& Albert, J. S. (2017). Coordinated dispersal and pre-isthmian assembly of the central american ichthyofauna. Systematic Biology, 66(2), 183-196. DOI: 10.1093/sysbio/syv064 


\section{DIGITAL APPENDIX}

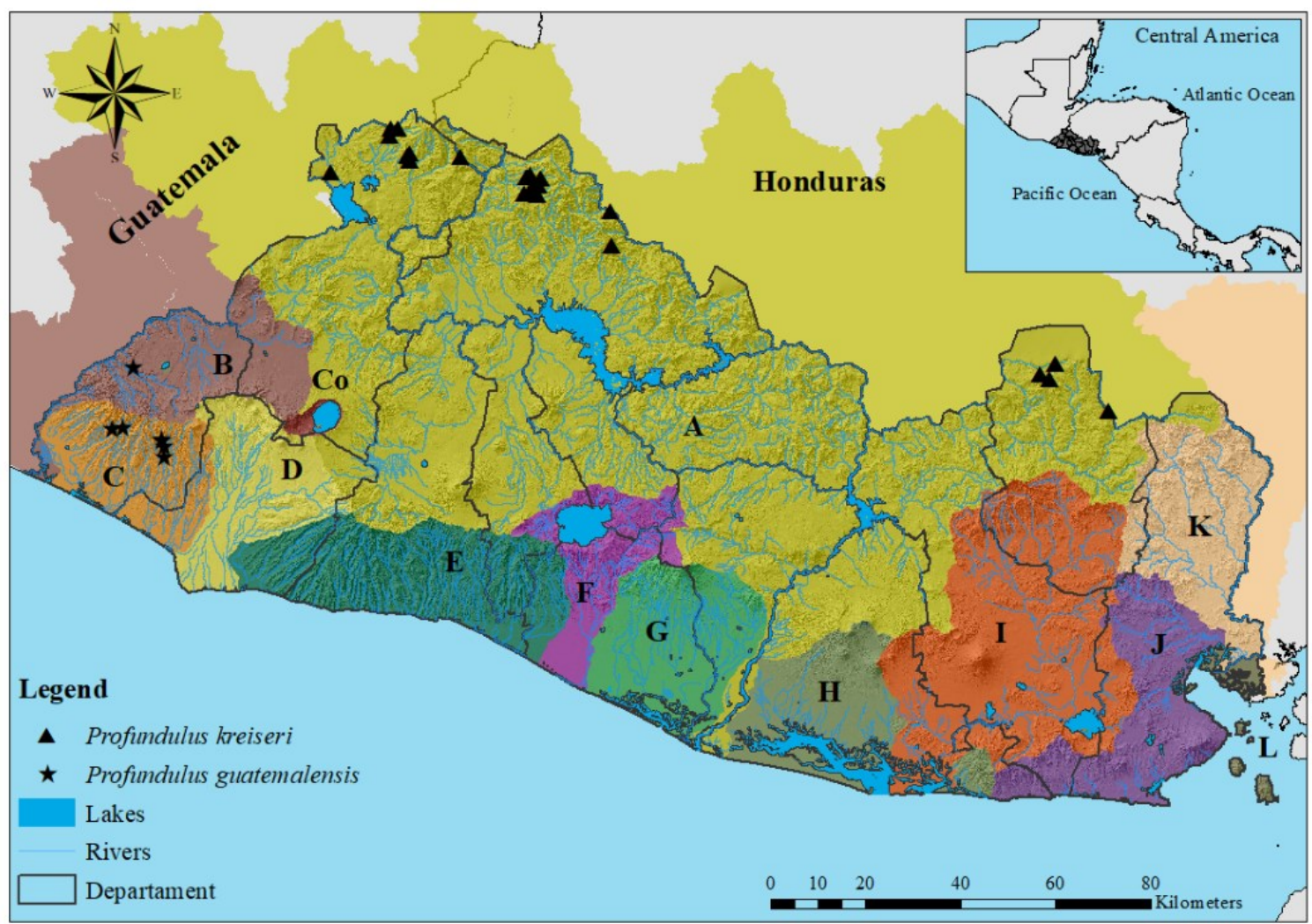

Fig. 1. Distribution of the genus Profundulus in El Salvador. Letters and colors on the map follow the classification presented in Figure 1. Profundulus guatemalensis; Drainages: Río Paz and Cara Sucia San Pedro; Department: Ahuachapán. Profundulus kreiseri; Drainages: Río Lempa; Departments: Santa Ana, Chalatenango, and Morazán. 


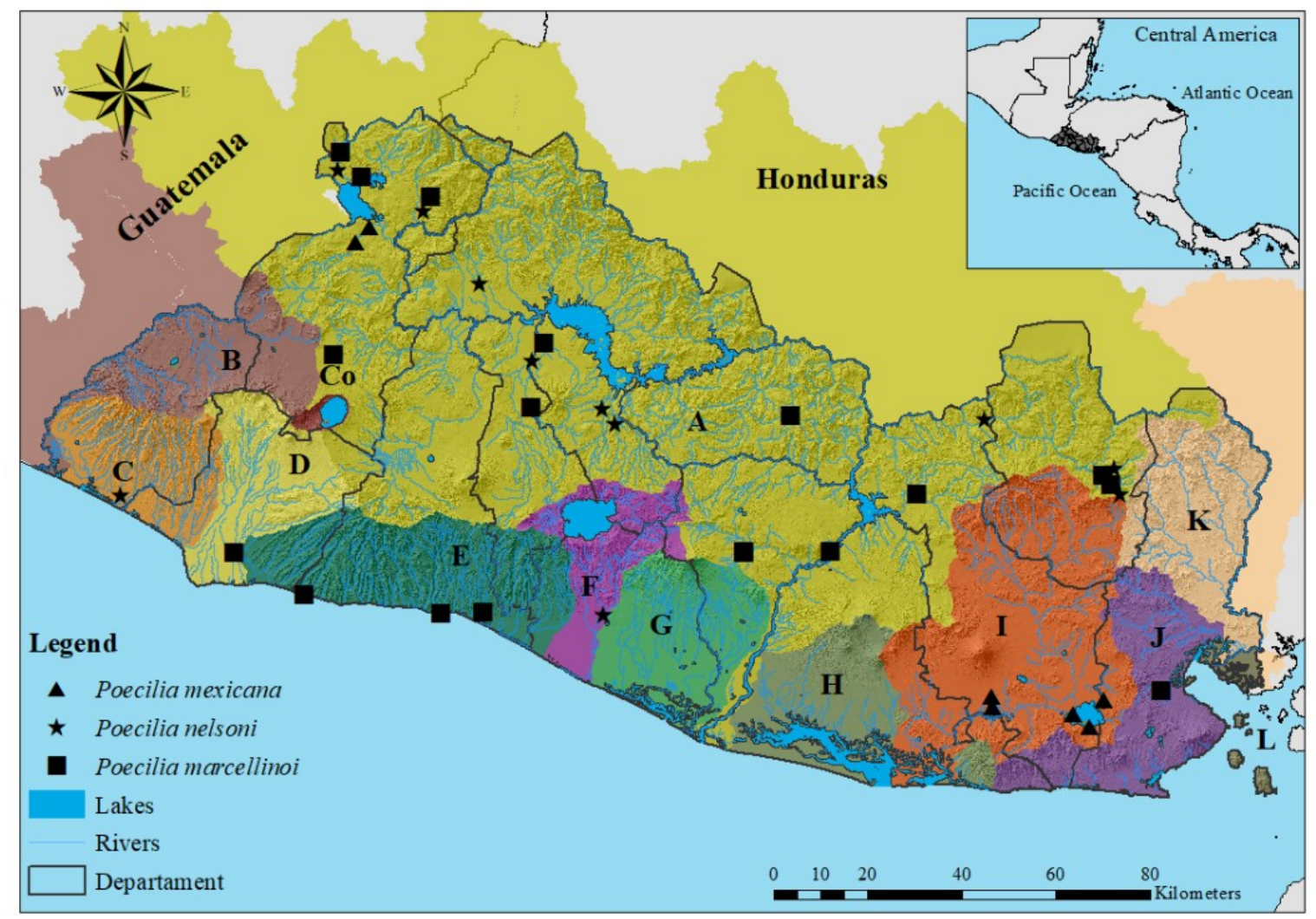

Fig. 2. Distribution of $P$. mexicana, $P$. nelsoni, and $P$. marcellinoi in El Salvador. Letters and colors on the map follow the classification presented in Figure 1. Poecilia mexicana; Drainages: Río Lempa and Río Grande de San Miguel;

Departments: Santa Ana, San Miguel, and La Unión. Poecilia nelsoni; Drainages: Río Lempa, Cara Sucia San Pedro, and

Río Jiboa; Departments: Santa Ana, Chalatenango, Ahuachapán, San Salvador, Cuscatlán, La Paz, San Miguel, and

Morazán. Poecilia marcellinoi; Drainages: Río Lempa, Río Grande de Sonsonate, Mandinga Comalapa, and Río Sirama; Departments: Santa Ana, Sonsonate, La Libertad, San Salvador, Cuscatlán, Cabañas, San Vicente, Usulután, San Miguel, Morazán, and La Unión. 


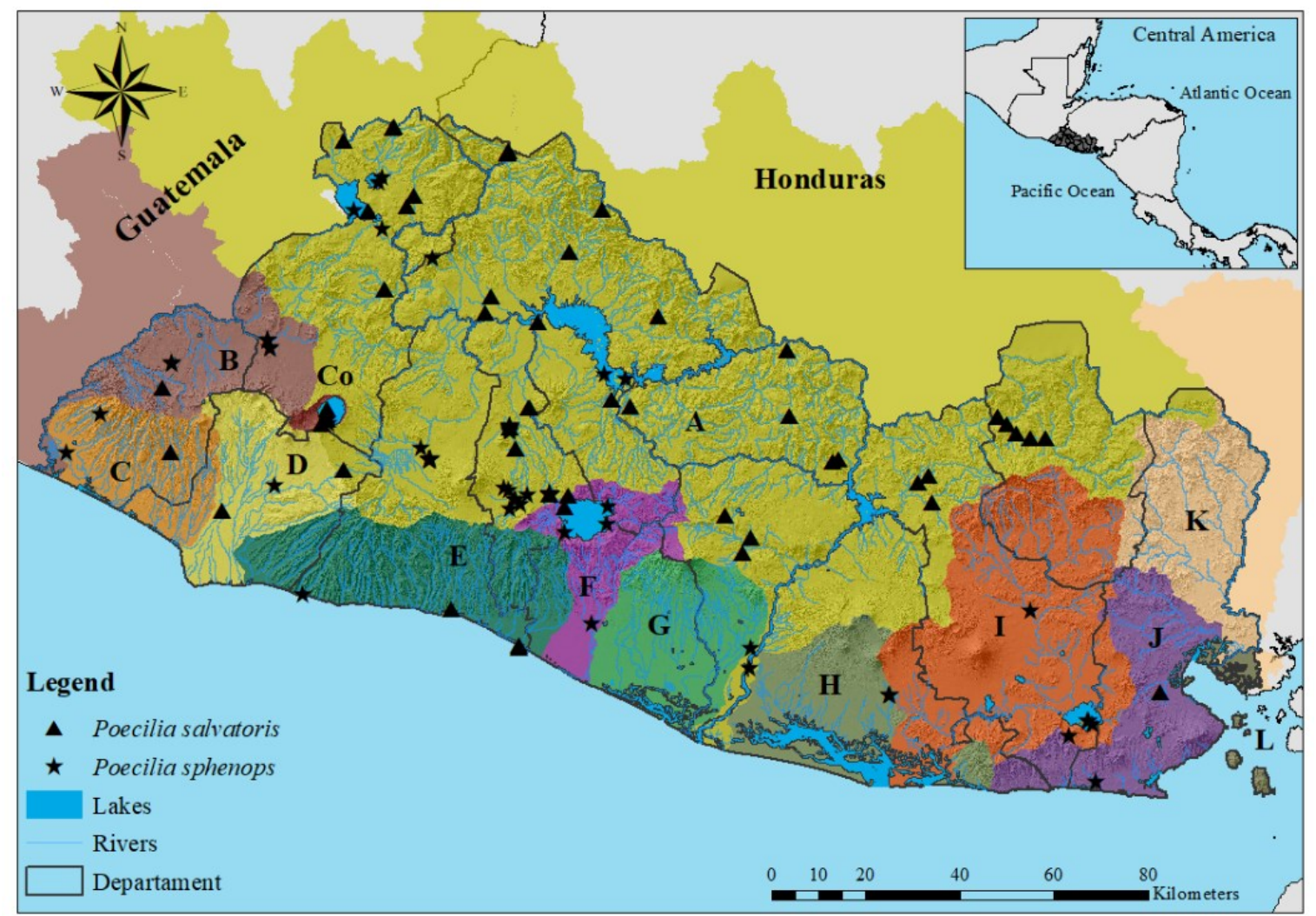

Fig. 3. Distribution of $P$. sphenops and $P$. salvatoris in El Salvador. Letters and colors on the map follow the classification presented in Figure 1. Poecilia salvatoris; Drainage: Río Lempa, Río Grande de Sonsonate, Mandinga Comalapa, and Río Sirama; Departments: Santa Ana, Sonsonate, La Libertad, San Salvador, Cuscatlán, Cabañas, San Vicente, Usulután, San Miguel, Morazán, and La Unión. Poecilia sphenops; Drainages: Río Lempa, Río Paz, Cara Sucia San Pedro, Río Grande de Sonsonate, Mandinga Comalapa, Río Jiboa, Bahía de Jiquilisco, Río Grande de San Miguel, Río Sirama, and Lago de Coatepeque; Departments: Santa Ana, Chalatenango, Sonsonate, La Libertad, San Salvador, Cuscatlán, La Paz, San Vicente, Usulután, San Miguel, Morazán, and La Unión. 


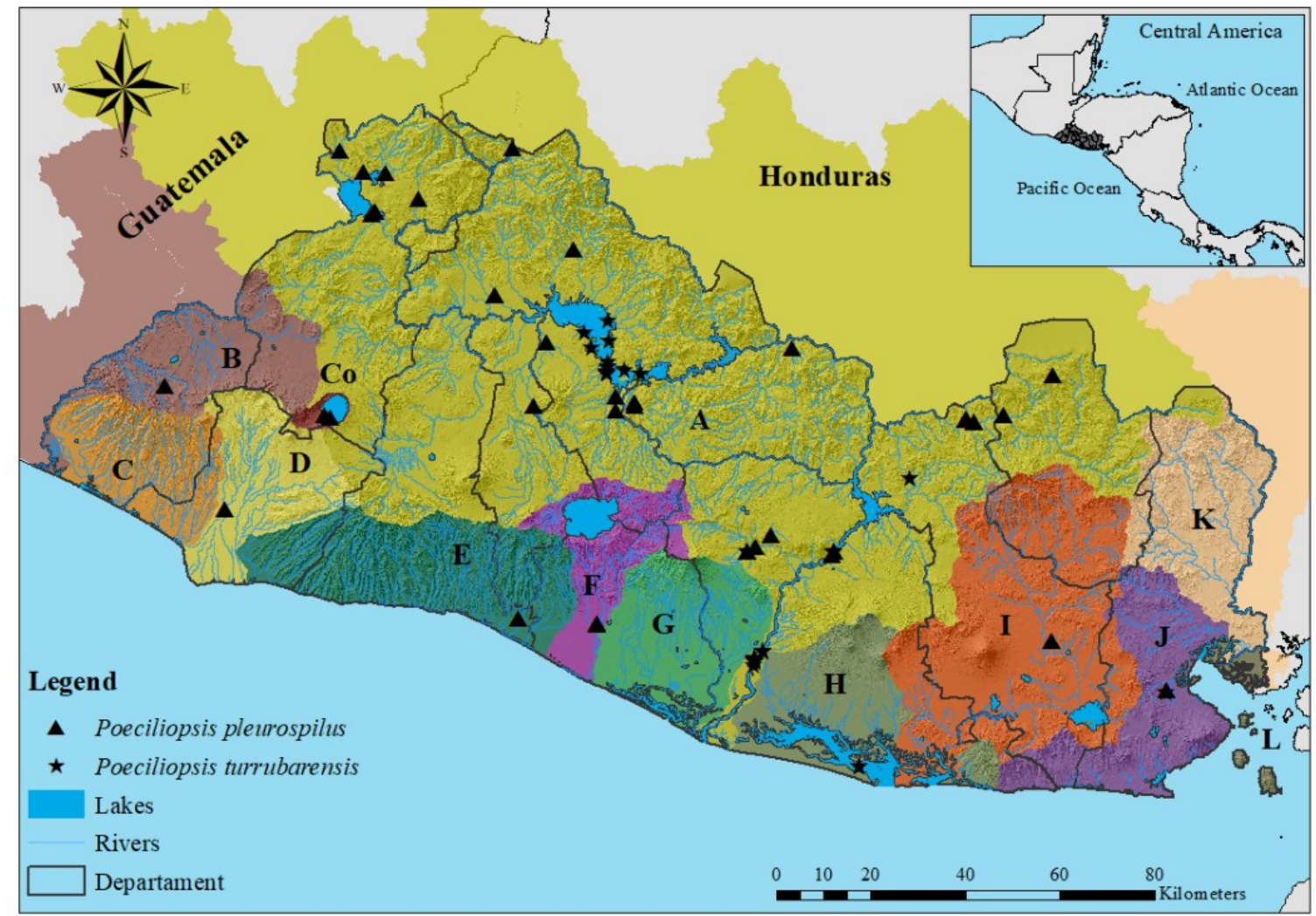

Fig. 4. Distribution of genus Poeciliopsis in El Salvador. Letters and colors on the map follow the classification presented in Figure 1. Poeciliopsis pleurospilus; Drainages: Río Lempa, Río Paz, Río Grande de Sonsonate, Mandinga Comalapa, Río Jiboa, Río Sirama, and Lago de Coatepeque; Departments: Santa Ana, Chalatenango, Sonsonate, La Libertad, San

Salvador, Cuscatlán, La Paz, Cabañas, San Vicente, Usulután, San Miguel, Morazán, and La Unión. Poeciliopsis turrubarensis; Drainages: Río Lempa, Jiquilisco Bay, and Río Sirama; Departments: Chalatenango, Cuscatlán, San Vicente, Usulután, and La Unión. 


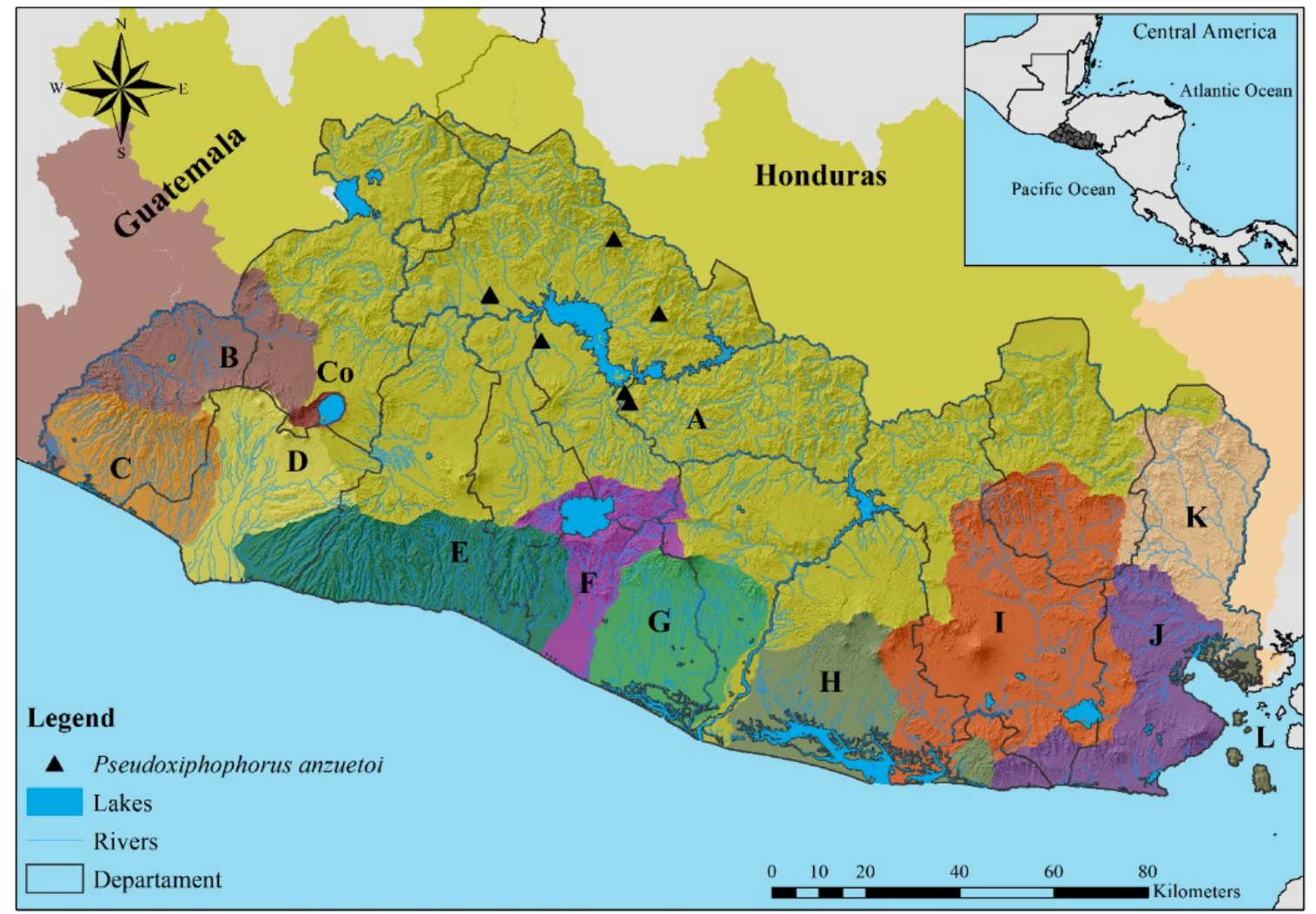

Fig. 5. Distribution of $P$. anzuetoi in El Salvador. Letters and colors on the map follow the classification presented in Figure 1. Pseudoxiphophorus anzuetoi; Drainages: Río Lempa; Departments: Chalatenango, Cuscatlán, and Cabañas. 


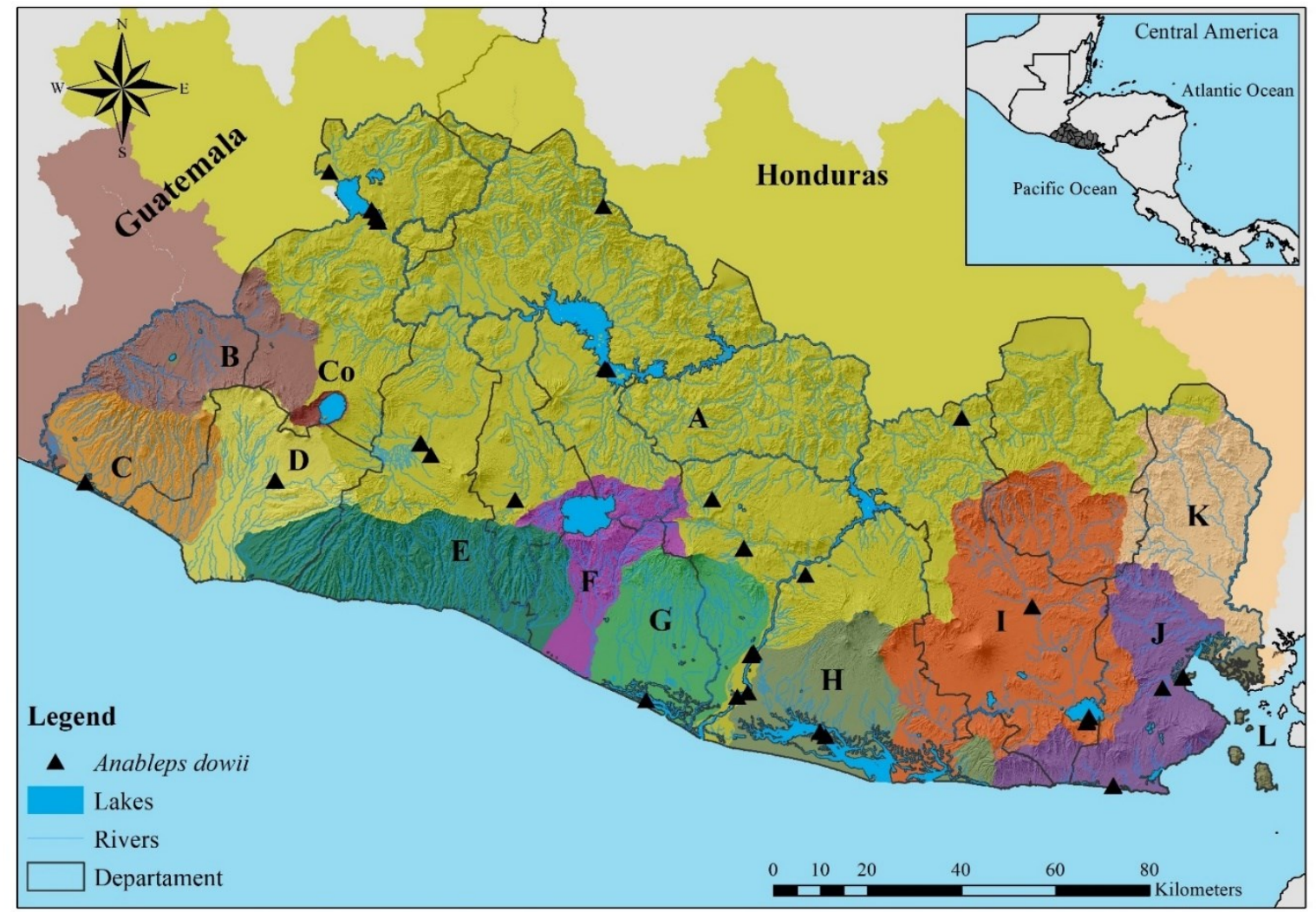

Fig. 6. Distribution of $A$. dowii in El Salvador. Letters and colors on the map follow the classification presented in Figure 1. Anableps dowii; Drainages: Río Lempa, Cara Sucia San Pedro, Rio Grande de Sonsonate Estero de Jaltepeque, Bahía de Jiquilisco, Río Grande de San Miguel, and Río Sirama; Departments: Santa Ana, Chalatenango, Sonsonate, La Libertad, San Salvador, Cuscatlán, San Vicente, Usulután, San Miguel, and La Unión. 


\section{TABLE 1}

Voucher specimens in ichthyological collections, year of collection, and geographical coordinates. Original geographical coordinates are represented with an asterisk $(*)$, otherwise coordinates correspond to original descriptions established according to the databases.

Species

Anableps dowii

Poecilia marcellinoi

Poecilia mexicana
Voucher, year, geographical coordinates

FMNH-12112; 1924; $\left(14^{\circ} 13^{\prime} 34.13^{\prime \prime} \mathrm{N} ; 8^{\circ} 27^{\prime} 25.3^{\prime \prime} \mathrm{W}\right), \mathrm{FMNH}-12114 ; 1924 ;\left(13^{\circ} 24^{\prime} 31.26^{\prime \prime} \mathrm{N}\right.$;

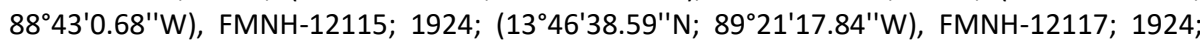

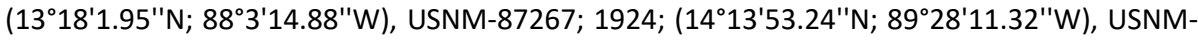

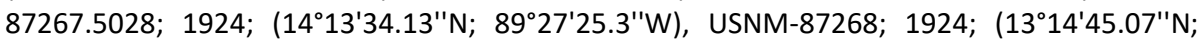
$\left.88^{\circ} 25^{\prime} 22.34^{\prime \prime W}\right)$, USNM-87268.5028; 1924; (13⒉'31.26"N; $\left.88^{\circ} 43^{\prime} 0.68^{\prime \prime} \mathrm{W}\right)$, USNM-87269; 1924; $\quad\left(13^{\circ} 33^{\prime} 39.6^{\prime \prime} \mathrm{N} ; \quad 88^{\circ} 35^{\prime} 34.44^{\prime \prime} \mathrm{W}\right), \quad$ USNM-87269.5028; $1924 ; \quad\left(13^{\circ} 46^{\prime} 38.58^{\prime \prime} \mathrm{N}\right.$;

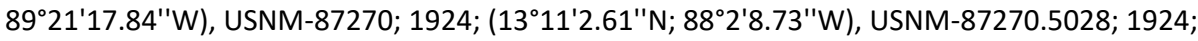

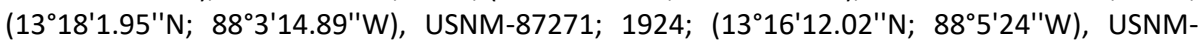

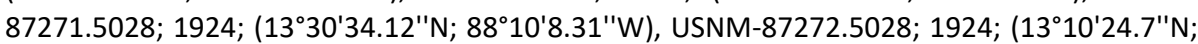

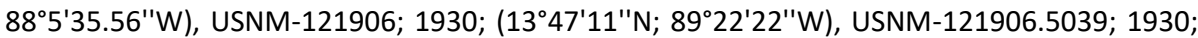
$\left(13^{\circ} 47^{\prime} 57.25^{\prime \prime} \mathrm{N} ; \quad 89^{\circ} 22^{\prime} 18.87^{\prime \prime} \mathrm{W}\right), \quad$ USNM-111421.1141; $1943 ; \quad\left(13^{\circ} 47^{\prime} 57.25^{\prime \prime} \mathrm{N}\right.$;

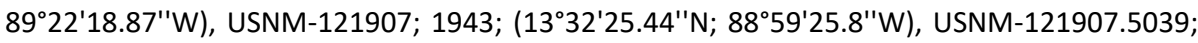

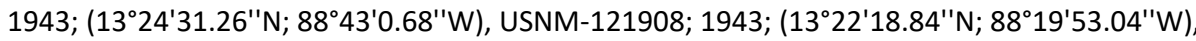
USNM-121908.5039; 1943; $\left(13^{\circ} 24^{\prime} 31.26^{\prime \prime} \mathrm{N} ; \quad 88^{\circ} 43^{\prime} 0.68^{\prime \prime} \mathrm{W}\right), \quad$ USNM-163932; 1953; $\left(14^{\circ} 7^{\prime} 50.93^{\prime \prime} \mathrm{N} ; 84^{\circ} 18^{\prime} 53.85^{\prime \prime W}\right)$, USNM-163932.505; 1953; (14²13'34.1"N; 89²7'25.3"W), TU202695; 1962; $\left(13^{\circ} 21^{\prime} 32.69^{\prime \prime} \mathrm{N} \text {; 87 } 54^{\prime} 47.95^{\prime \prime} \mathrm{W}\right)^{*}$, MUHNES-40-376; 1973; $\left(13^{\circ} 20^{\prime} 6.41^{\prime \prime} \mathrm{N}\right.$; $\left.88^{\circ} 43^{\prime} 21.86^{\prime \prime} \mathrm{W}\right)^{*}$, MUHNES-40-110; 1991; $\left(13^{\circ} 42^{\prime} 34.52^{\prime \prime} \mathrm{N} ; 90^{\circ} 1^{\prime} 36.45^{\prime \prime W}\right)^{*}$, USNM-

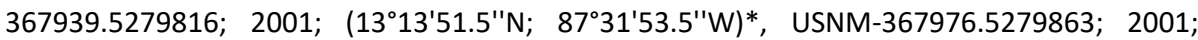

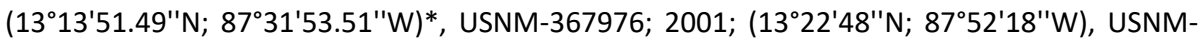

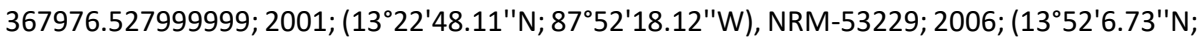
$\left.88^{\circ} 18^{\prime} 48.6^{\prime \prime} \mathrm{W}\right), \quad \mathrm{NRM}-53333 ; 2006$; $\left(14^{\circ} 18^{\prime} 53.28^{\prime \prime} \mathrm{N}\right.$; 89³3'48.6"W), NRM-53374; 2006; $\left(14^{\circ} 14^{\prime} 35.58^{\prime \prime} \mathrm{N} ; 89^{\circ} 28^{\prime} 45.48^{\prime \prime} \mathrm{W}\right), \mathrm{NRM}-53470 ; 2006$; $\left(14^{\circ} 14^{\prime} 35.52^{\prime \prime} \mathrm{N} ; 89^{\circ} 28^{\prime} 45.48^{\prime \prime} \mathrm{W}\right), \mathrm{KU}-$

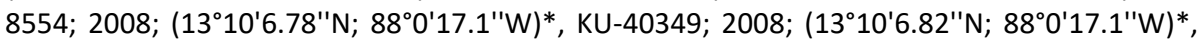

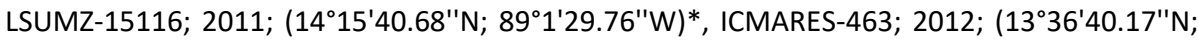

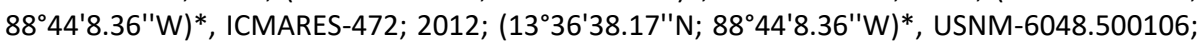

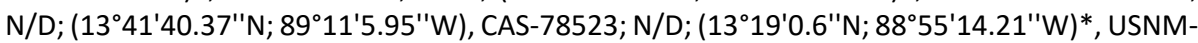
87272; 1924; (134' $\left.15.25^{\prime \prime} \mathrm{N} ; 89^{\circ} 39^{\prime} 23.66^{\prime \prime} \mathrm{W}\right)$.

UMMZ-202789; 1959; $\left(13^{\circ} 27^{\prime} 0.05^{\prime \prime} \mathrm{N} ; 99^{\circ} 58^{\prime} 60^{\prime \prime} \mathrm{W}\right)^{*}$, UMMZ-202796; 1959; $\left(13^{\circ} 32^{\prime} 4.52^{\prime \prime} \mathrm{N}\right.$;

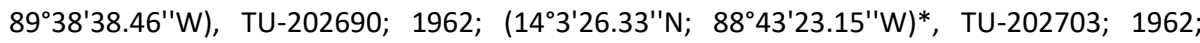

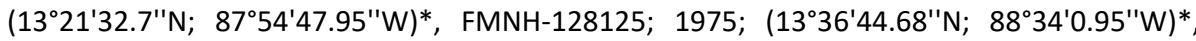
LSUMZ-15070; 2011; (13²9'4.1"N; 89¹4'45.1"W)*, LSUMZ-15073; 2011; (13²8'51.32"N;

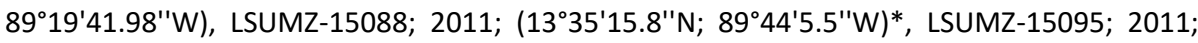

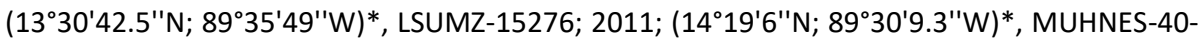

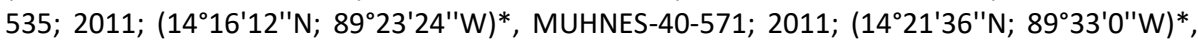

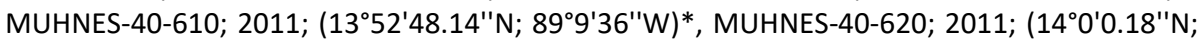

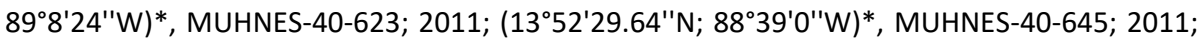
$\left(13^{\circ} 43^{\prime} 48.05^{\prime \prime} \mathrm{N} ; 88^{\circ} 24^{\prime} 0^{\prime \prime} \mathrm{W}\right) *$, MUHNES-40-655; 2011; $\left(13^{\circ} 44^{\prime} 56.48^{\prime \prime} \mathrm{N} ; 88^{\circ} 0^{\prime} 59.63^{\prime \prime} \mathrm{W}\right)^{*}$,

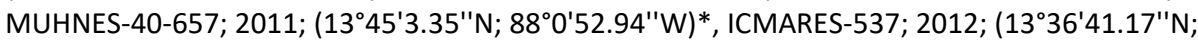

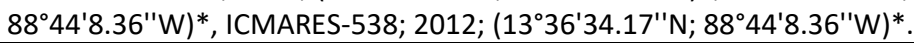

SA-184877; 1998; $\left(13^{\circ} 19^{\prime} 36.97^{\prime \prime N} ; \quad 88^{\circ} 2^{\prime} 6.32^{\prime \prime W}\right), \quad S A-184885 ; \quad 1998 ; \quad\left(13^{\circ} 19^{\prime} 36.97^{\prime \prime} \mathrm{N}\right.$; $\left.88^{\circ} 2^{\prime} 6.32^{\prime \prime W}\right), \quad S A-184934 ; 1998 ; \quad\left(13^{\circ} 18^{\prime} 26.01^{\prime \prime} \mathrm{N} ; \quad 88^{\circ} 1^{\prime} 48.59^{\prime \prime} \mathrm{W}\right), \quad S A-184786 ; 1998 ;$

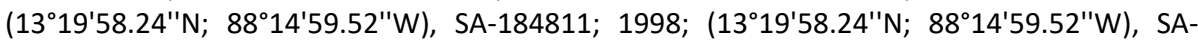
184691; 1999; $\quad\left(14^{\circ} 13^{\prime} 42.76^{\prime \prime} \mathrm{N} ; \quad 89^{\circ} 28^{\prime} 21.42^{\prime \prime} \mathrm{W}\right), \quad \mathrm{SA}-184823 ; \quad 1999 ; \quad\left(14^{\circ} 13^{\prime} 42.76^{\prime \prime} \mathrm{N}\right.$; $\left.89^{\circ} 28^{\prime} 21.42^{\prime \prime} \mathrm{W}\right)$. UMMZ-202797; 1959; $\left(13^{\circ} 28^{\prime} 0^{\prime \prime} \mathrm{N} ; \quad 90^{\circ} 37^{\prime} 60^{\prime \prime} \mathrm{W}\right), \quad \mathrm{NRM}-53316 ; \quad 2006 ; \quad\left(13^{\circ} 27^{\prime} 59.4^{\prime \prime} \mathrm{N}\right.$;

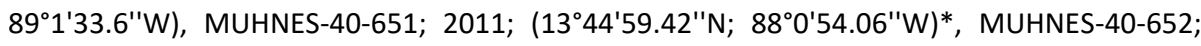
2011; $\quad\left(13^{\circ} 44^{\prime} 57.48^{\prime \prime} \mathrm{N} ; \quad 88^{\circ} 0^{\prime} 56.93^{\prime \prime} \mathrm{W}\right)^{*}, \quad$ MUHNES-40-532; 2011; $\quad\left(14^{\circ} 16^{\prime} 12.07^{\prime \prime} \mathrm{N}\right.$; $\left.89^{\circ} 23^{\prime} 24^{\prime \prime W}\right)^{*}$, MUHNES-40-552; 2011; (145'24.07"N; 89¹4'24"W)*, MUHNES-40-570; 2011;

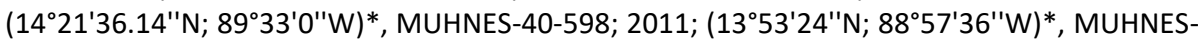

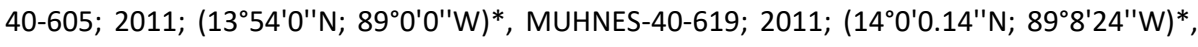
MUHNES-40-668; 2011; $\left(13^{\circ} 52^{\prime} 48.04^{\prime \prime} \mathrm{N} ; 88^{\circ} 14^{\prime} 24^{\prime \prime} \mathrm{W}\right)^{*}$. 
Poecilia salvatoris $\quad$ USNM-84361; $1921 ; \quad\left(13^{\circ} 25^{\prime} 16.04^{\prime \prime N} ; \quad 89^{\circ} 5^{\prime} 44.31^{\prime \prime W}\right), \quad$ USNM-84361.50268; 1921; $\left(13^{\circ} 50^{\prime} 27.24^{\prime \prime N}\right.$; 89¹1'52.26"W), UMMZ-181821; 1958; (1350'57.57"N; 89³3'25.07"W), UMMZ-202774; 1959; (1348'0.06"N; 9046'60"W)*, UMMZ-202776; 1959; $\left(13^{\circ} 48^{\prime} 0.04^{\prime \prime} \mathrm{N}\right.$;

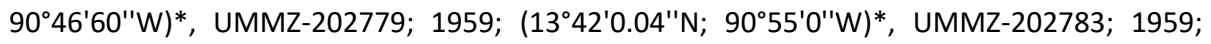
$\left(13^{\circ} 42^{\prime} 0.05^{\prime \prime N} \text {; } 90^{\circ} 57^{\prime} 0^{\prime \prime} \mathrm{W}\right)^{*}, \mathrm{UMMZ}-202788 ; 1959 ;\left(13^{\circ} 27^{\prime} 0.04^{\prime \prime} \mathrm{N} ; 99^{\circ} 58^{\prime} 60^{\prime \prime} \mathrm{W}\right)^{*}, \mathrm{UMMZ}-$

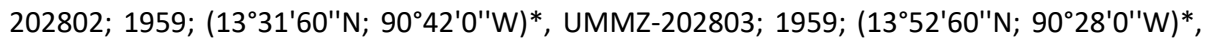

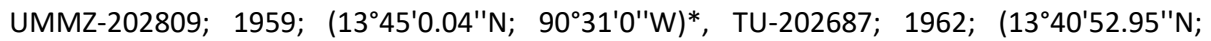

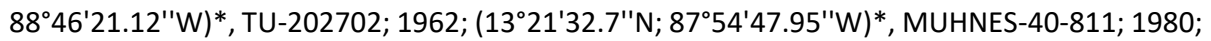
$\left(13^{\circ} 25^{\prime} 12^{\prime \prime} \mathrm{N} ; 8^{\circ} 10^{\prime} 12^{\prime \prime} \mathrm{W}\right)^{*}$, MUHNES-40-812; 1980; $\left(13^{\circ} 25^{\prime} 12.07^{\prime \prime} \mathrm{N} ; 8^{\circ} 10^{\prime} 12^{\prime \prime} \mathrm{W}\right)^{*}$, LSUMZ-

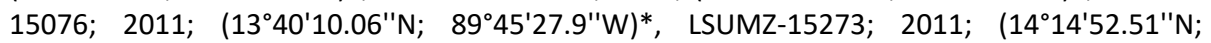

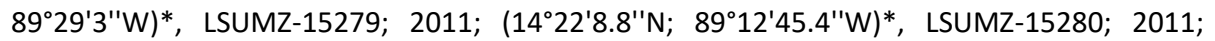

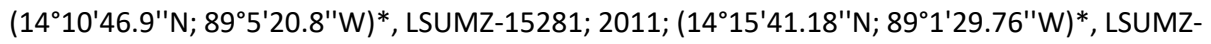
15282; 2011; $\left(13^{\circ} 54^{\prime} 6.1^{\prime \prime} \mathrm{N} ; \quad 89^{\circ} 52^{\prime} 52.3^{\prime \prime} \mathrm{W}\right)^{*}$, MUHNES-40-517; 2011; $\left(13^{\circ} 37^{\prime} 12^{\prime \prime} \mathrm{N}\right.$;

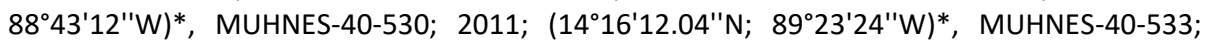

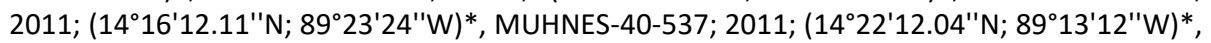

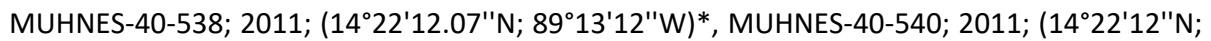

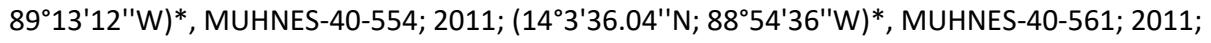
$\left(14^{\circ} 5^{\prime} 24.14^{\prime \prime N} \text {; 89 } 14^{\prime} 24^{\prime \prime} \mathrm{W}\right)^{*}$, MUHNES-40-562; 2011; $\left(14^{\circ} 6^{\prime} 0^{\prime \prime} \mathrm{N} ; 89^{\circ} 27^{\prime} 0^{\prime \prime} \mathrm{W}\right) *$, MUHNES-40569; 2011; $\left(14^{\circ} 21^{\prime} 36.11^{\prime \prime} \mathrm{N} ; \quad 89^{\circ} 33^{\prime} 0^{\prime \prime} \mathrm{W}\right)^{*}, \quad$ MUHNES-40-576; 2011; $\quad\left(14^{\circ} 24^{\prime} 36.07^{\prime \prime} \mathrm{N}\right.$; $\left.89^{\circ} 26^{\prime} 24^{\prime \prime} \mathrm{W}\right)^{*}$, MUHNES-40-580; 2011; $\left(14^{\circ} 8^{\prime} 24.11^{\prime \prime} \mathrm{N} ; 89^{\circ} 1^{\prime} 12^{\prime \prime} \mathrm{W}\right)^{*}$, MUHNES-40-585; 2011;

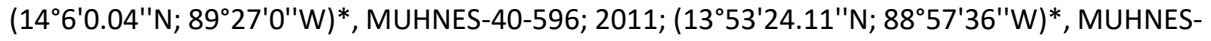
40-604; 2011; $\left(13^{\circ} 54^{\prime} 0.07^{\prime \prime} \mathrm{N} ; \quad 89^{\circ} 0^{\prime} 0^{\prime \prime} \mathrm{W}\right)^{*}$, MUHNES-40-609; 2011; $\left(13^{\circ} 52^{\prime} 48.11^{\prime \prime} \mathrm{N}\right.$; $\left.89^{\circ} 9^{\prime} 36^{\prime \prime W}\right)^{*}$, MUHNES-40-611; 2011; (1352'48.05"N; 899'36"W)*, MUHNES-40-618; 2011; $\left(14^{\circ} 0^{\prime} 0.11^{\prime \prime N}\right.$; 898'24"W)*, MUHNES-40-624; 2011; (1352'30"N; 88³9'0"W)*, MUHNES-40-

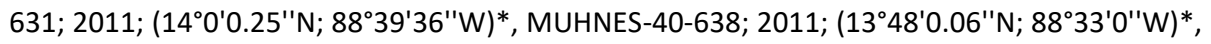

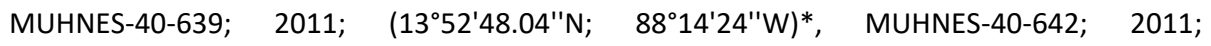
$\left(13^{\circ} 43^{\prime} 48.04^{\prime \prime N} \text {; } 88^{\circ} 24^{\prime} 0^{\prime \prime} \mathrm{W}\right)^{*}$, MUHNES-40-644; 2011; $\left(13^{\circ} 43^{\prime} 48.04^{\prime \prime} \mathrm{N} ; 88^{\circ} 24^{\prime} \mathrm{O}^{\prime \prime} \mathrm{W}\right)^{*}$, MUHNES-40-646; 2011; $\left(13^{\circ} 43^{\prime} 48.05^{\prime \prime} \mathrm{N}\right.$; 88²4'0"W)*, MUHNES-40-649; 2011; $\left(13^{\circ} 45^{\prime} 0.05^{\prime \prime} \mathrm{N}\right.$;

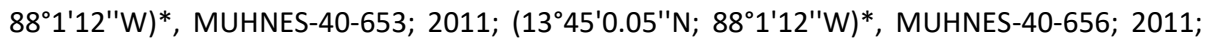

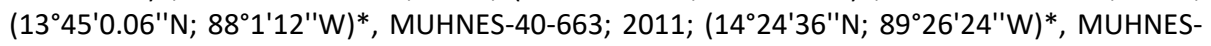

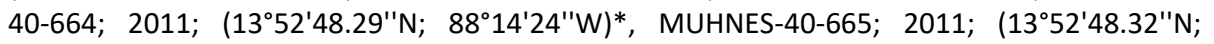

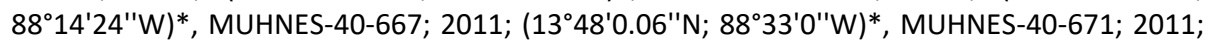
$\left(13^{\circ} 52^{\prime} 48.25^{\prime \prime} \mathrm{N} ; 88^{\circ} 14^{\prime} 24^{\prime \prime} \mathrm{W}\right)^{*}$, ICMARES-514; 2012 ; $\left(13^{\circ} 36^{\prime} 37.17^{\prime \prime} \mathrm{N} ; 88^{\circ} 44^{\prime} 8.36^{\prime \prime} \mathrm{W}\right)^{*}$, LSUMZ17755; 2013; $\left(13^{\circ} 50^{\prime} 57.58^{\prime \prime} \mathrm{N} ; \quad 89^{\circ} 33^{\prime} 25.07^{\prime \prime} \mathrm{W}\right)$, LSUMZ-17762; 2013; $\left(13^{\circ} 46^{\prime} 41.3^{\prime \prime} \mathrm{N}\right.$; $\left.89^{\circ} 51^{\prime} 41.3^{\prime \prime} \mathrm{W}\right)^{*}$.

Poecilia sphenops $\quad$ USNM-84352; $1921 ; \quad\left(13^{\circ} 25^{\prime} 21.05^{\prime \prime} \mathrm{N} ; \quad 89^{\circ} 5^{\prime} 44.31^{\prime \prime} \mathrm{W}\right), \quad$ USNM-84352.50268; 1921 ; $\left(13^{\circ} 50^{\prime} 27.24^{\prime \prime N}\right.$; 89¹1'52.26"W), USNM-84353; 1921; (13²5'21.43"N; 895'44.31"W), USNM-

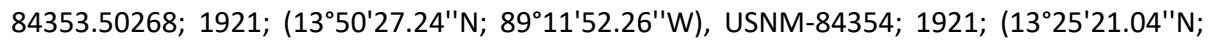
$\left.89^{\circ} 5^{\prime} 44.31^{\prime \prime W}\right)$, USNM-84354.50268; 1921; (1350'27.24"N; 89¹1'52.26"W), USNM-84355; 1921; (13 $25^{\prime} 21.04^{\prime \prime N}$; $\left.89^{\circ} 5^{\prime} 44.31^{\prime \prime W}\right), \quad$ USNM-84355.50268; $1921 ; \quad\left(13^{\circ} 50^{\prime} 27.24^{\prime \prime} \mathrm{N}\right.$; 89¹1'52.26"W), USNM-84356; 1921; (13²5'16.04"N; 895'41.96"W), USNM-84356.50268;

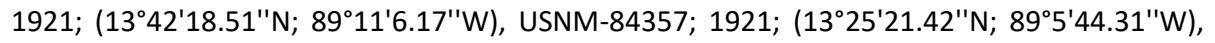

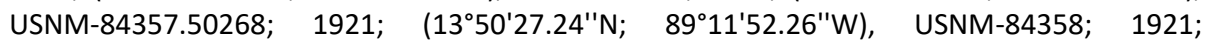
$\left(13^{\circ} 25^{\prime} 21.42^{\prime \prime N}\right.$; 895'44.31"W), USNM-84358.50268; 1921; (1350'27.24"N; 89॰11'52.26"W), USNM-84359; 1921; $\left(13^{\circ} 25^{\prime} 21.4^{\prime \prime} \mathrm{N} ; \quad 89^{\circ} 5^{\prime} 44.31^{\prime \prime W}\right), \quad$ USNM-84359.50268; 1921; $\left(13^{\circ} 50^{\prime} 27.24^{\prime \prime} \mathrm{N} ; 8^{\circ} 11^{\prime} 52.26^{\prime \prime} \mathrm{W}\right)$, USNM-84360; $1921 ;\left(13^{\circ} 25^{\prime} 16.05^{\prime \prime} \mathrm{N} ; 89^{\circ} 5^{\prime} 41.96^{\prime \prime} \mathrm{W}\right)$, USNM84360.50268; 1921; (1342'18.51"N; 89¹1'6.18"W), USNM-85420; 1921; (1324'54.79"N; $\left.89^{\circ} 6^{\prime} 1.3^{\prime \prime W}\right)$, USNM-85420.5027399999; 1921; $\left(13^{\circ} 50^{\prime} 27.28^{\prime \prime} \mathrm{N} ; 89^{\circ} 11^{\prime} 52.26^{\prime \prime} \mathrm{W}\right), \quad$ USNM85421; 1921; (13²4'54.8"N; 896'1.3'W), USNM-85421.5027399999; 1921; (1350'27.24"N; $\left.89^{\circ} 11^{\prime} 52.26^{\prime \prime} \mathrm{W}\right), \mathrm{FMNH}-12051 ; 1924 ;\left(14^{\circ} 13^{\prime} 34.13^{\prime \prime} \mathrm{N} ; 89^{\circ} 27^{\prime} 25.3^{\prime \prime} \mathrm{W}\right), \mathrm{FMNH}-12052 ; 1924 ;$ $\left(13^{\circ} 50^{\prime 2} 27.24^{\prime \prime} \mathrm{N} ; 8^{\circ} 11^{\prime} 52.26^{\prime \prime} \mathrm{W}\right), \mathrm{FMNH}-12053 ; 1924 ;\left(13^{\circ} 39^{\prime} 7.85^{\prime \prime} \mathrm{N} ; 8^{\circ} 2^{\prime} 22.98^{\prime \prime} \mathrm{W}\right), \mathrm{FMNH}-$ 12054; 1924; $\left(13^{\circ} 46^{\prime} 38.62^{\prime \prime N} ; \quad 89^{\circ} 21^{\prime} 17.84^{\prime \prime W}\right), \quad$ USNM-87232; 1924; $\left(14^{\circ} 9^{\prime} 45.68^{\prime \prime} \mathrm{N}\right.$; $\left.89^{\circ} 18^{\prime} 40.5^{\prime \prime} \mathrm{W}\right)$, USNM-87232.5028; 1924; (14²15'5.2"N; 89³0'45.14"W), USNM-87233; 1924;

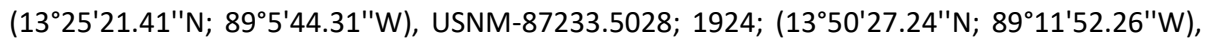

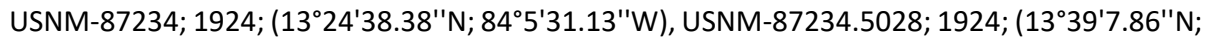

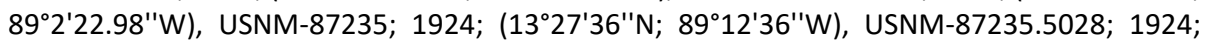
$\left(13^{\circ} 46^{\prime} 38.54^{\prime \prime} \mathrm{N} ; 89^{\circ} 21^{\prime} 17.84^{\prime \prime} \mathrm{W}\right)$, USNM-87236; 1924; $\left(13^{\circ} 35^{\prime} 24^{\prime \prime N}\right.$; $\left.89^{\circ} 24^{\prime} 0^{\prime \prime} \mathrm{W}\right)$, USNM-

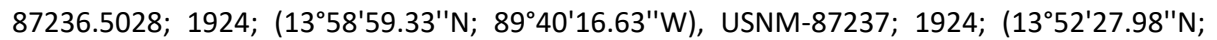


89¹9'48"W), USNM-87237.5028; 1924; (1350'57.57"N; 89³3'25.07'"W), USNM-87238; 1924;

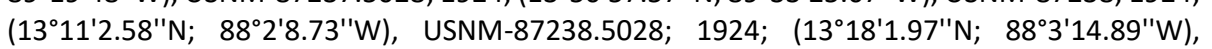

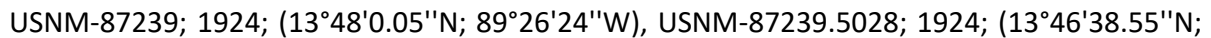

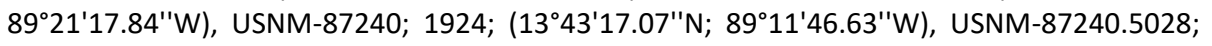

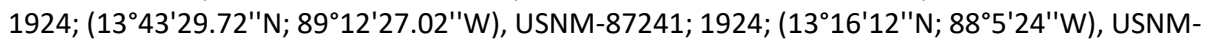

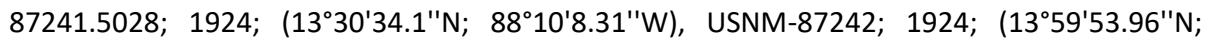
$\left.89^{\circ} 40^{\prime} 31.96^{\prime \prime W}\right)$, USNM-87242.5028; 1924; (1359'53.96"N; 8940'31.95"W), USNM-87243; 1924; $\quad\left(13^{\circ} 47^{\prime} 10.97^{\prime \prime} \mathrm{N} ; \quad 89^{\circ} 22^{\prime} 22^{\prime \prime} \mathrm{W}\right), \quad$ USNM-87243.5028; $1924 ; \quad\left(13^{\circ} 47^{\prime} 57.25^{\prime \prime} \mathrm{N}\right.$; $\left.89^{\circ} 22^{\prime} 18.87^{\prime \prime} \mathrm{W}\right)$, USNM-87244; 1924; (133' $\left.39.64^{\prime \prime} \mathrm{N} ; 8^{\circ} 35^{\prime} 34.44^{\prime \prime} \mathrm{W}\right)$, USNM-87244.5028;

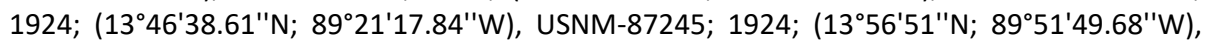
USNM-87245.5028; 1924; $\left(13^{\circ} 57^{\prime} 6.27^{\prime \prime} \mathrm{N} ; \quad 89^{\circ} 51^{\prime} 46.29^{\prime \prime} \mathrm{W}\right), \quad$ USNM-87246; 1924;

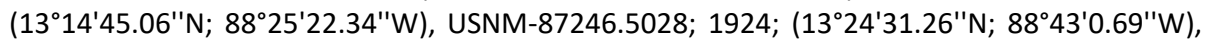
USNM-87247; 1924; $\quad\left(14^{\circ} 18^{\prime} 56.27^{\prime \prime} \mathrm{N} ; \quad 89^{\circ} 27^{\prime} 33.01^{\prime \prime W}\right), \quad$ USNM-87247.5028; 1924;

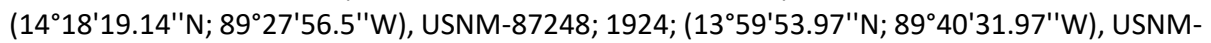

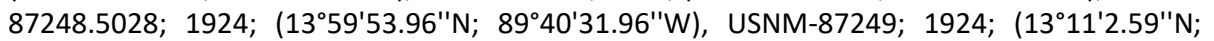

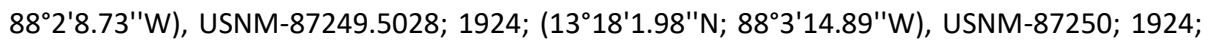
$\left(13^{\circ} 46^{\prime} 38.6^{\prime \prime} \mathrm{N} ; 89^{\circ} 21^{\prime} 17.84^{\prime \prime}\right)$, USNM-87250.5028; 1924; (1346'38.55"N; 89²1'17.84"W),

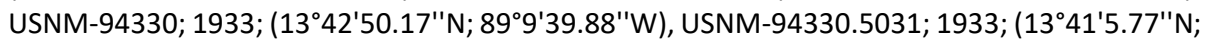
$\left.89^{\circ} 11^{\prime} 39.42^{\prime \prime W}\right)$, USNM-196364; 1961; (13²0'37.16"N; 88²6'41.79"'W), USNM-196364.5058; 1961; $\left(13^{\circ} 20^{\prime} 37.16^{\prime \prime} \mathrm{N}\right.$; 88²6'41.8"W), MUHNES-40-282; 1979; $\left(13^{\circ} 51^{\prime} 0^{\prime \prime} \mathrm{N} ; 90^{\circ} 0^{\prime} 0^{\prime \prime} \mathrm{W}\right)^{*}$,

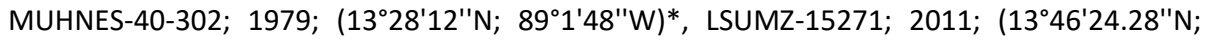
$\left.90^{\circ} 3^{\prime} 51.3^{\prime \prime} \mathrm{W}\right)$, LSUMZ-15272; 2011; (1330'51.3"N; 89³5'45.9"W)*.

Poeciliopsis pleurospilus
TU-202680; 1962; $\left(13^{\circ} 27^{\prime} 0.05^{\prime \prime} \mathrm{N} ; 8^{\circ} 8^{\prime} 18.74^{\prime \prime} \mathrm{W}\right) *$ TU-202700; $1962 ; \quad\left(13^{\circ} 21^{\prime} 32.69^{\prime \prime} \mathrm{N}\right.$; $\left.87^{\circ} 54^{\prime} 47.95^{\prime \prime} \mathrm{W}\right)^{*}, \mathrm{FMNH}-128124 ; 1975 ;\left(13^{\circ} 36^{\prime} 44.68^{\prime \prime} \mathrm{N} ; 88^{\circ} 34^{\prime} 0.95^{\prime \prime W}\right)^{*}, \mathrm{NRM}-53230 ; 2006$; $\left(13^{\circ} 52^{\prime} 6.74^{\prime \prime N} \text {; 88 } 18^{\prime} 48.6^{\prime \prime} \mathrm{W}\right)^{*}, \mathrm{NRM}-53231 ; 2006$; $\left(13^{\circ} 52^{\prime} 6.78^{\prime \prime} \mathrm{N} ; 88^{\circ} 18^{\prime} 48.6^{\prime \prime} \mathrm{W}\right) *$, NRM53232; 2006; $\left(13^{\circ} 52^{\prime} 6.82^{\prime \prime} \mathrm{N} ; \quad 88^{\circ} 18^{\prime} 48.6^{\prime \prime} \mathrm{W}\right)^{*}$, NRM-53233; 2006; $\left(13^{\circ} 52^{\prime} 6.85^{\prime \prime} \mathrm{N}\right.$;

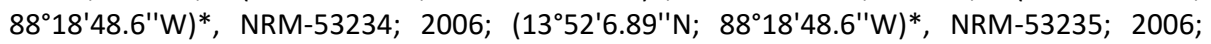
$\left(13^{\circ} 52^{\prime} 6.92^{\prime \prime} \mathrm{N} ; 88^{\circ} 18^{\prime} 48.6^{\prime \prime} \mathrm{W}\right)^{*}, \mathrm{NRM}-53236 ; 2006$; $\left(13^{\circ} 52^{\prime} 6.64^{\prime \prime} \mathrm{N} ; 88^{\circ} 18^{\prime} 48.6^{\prime \prime} \mathrm{W}\right)^{*}, \mathrm{NRM}-$ 53237; 2006; $\left(13^{\circ} 52^{\prime} 6.64^{\prime \prime N} \text {; } 88^{\circ} 18^{\prime} 48.6^{\prime \prime} \mathrm{W}\right)^{*}$, NRM-53238; 2006; $\left(13^{\circ} 52^{\prime} 6.65^{\prime \prime} \mathrm{N}\right.$;

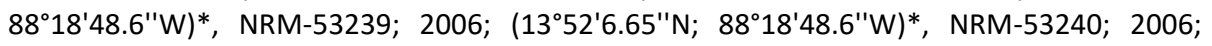

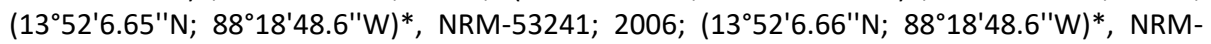
53242; 2006; $\left(13^{\circ} 52^{\prime} 6.86^{\prime \prime} \mathrm{N} ; \quad 88^{\circ} 18^{\prime} 48.6^{\prime \prime} \mathrm{W}\right)^{*}$, NRM-53243; 2006; $\left(13^{\circ} 52^{\prime} 6.66^{\prime \prime} \mathrm{N}\right.$;

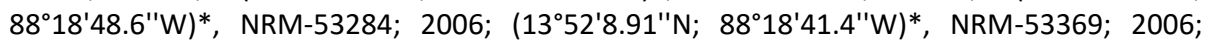
$\left(14^{\circ} 14^{\prime} 35.7^{\prime \prime} \mathrm{N} ; 8^{\circ} 28^{\prime} 45.48^{\prime \prime} \mathrm{W}\right)^{*}$, NRM-53371; 2006; (14²14'35.74"N; 89²8'45.48'"W)*, NRM53372; 2006; $\left(14^{\circ} 14^{\prime} 35.77^{\prime \prime} \mathrm{N} ; \quad 89^{\circ} 28^{\prime} 45.48^{\prime \prime} \mathrm{W}\right) *$, NRM-53401; 2006; $\left(13^{\circ} 27^{\prime} 59.41^{\prime \prime} \mathrm{N}\right.$;

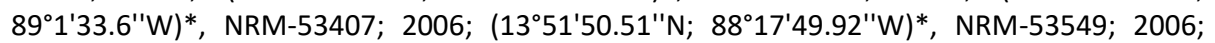

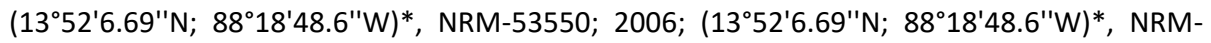
53551; 2006; $\quad\left(13^{\circ} 52^{\prime} 6.7^{\prime \prime} \mathrm{N} ; \quad 88^{\circ} 18^{\prime} 48.6^{\prime \prime} \mathrm{W}\right)^{*}, \quad \mathrm{NRM}-53552 ; \quad 2006 ; \quad\left(13^{\circ} 52^{\prime} 6.7^{\prime \prime} \mathrm{N}\right.$; $\left.88^{\circ} 18^{\prime} 48.6^{\prime \prime} \mathrm{W}\right)^{*}$, NRM-53553; 2006; $\left(13^{\circ} 52^{\prime} 6.7^{\prime \prime} \mathrm{N} ; 8^{\circ} 18^{\prime} 48.6^{\prime \prime} \mathrm{W}\right)^{*}, \quad \mathrm{NRM}-53554 ; 2006$;

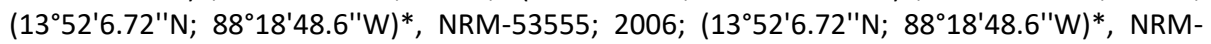
53556; 2006; $\quad\left(13^{\circ} 52^{\prime} 6.72^{\prime \prime N} \text {; } 88^{\circ} 18^{\prime} 48.6^{\prime \prime} \mathrm{W}\right)^{*}$, NRM-53557; 2006; $\left(13^{\circ} 52^{\prime} 6.73^{\prime \prime} \mathrm{N}\right.$;

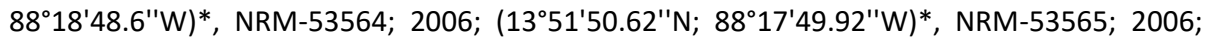

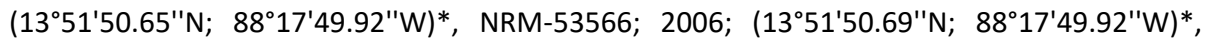

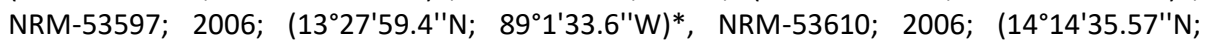

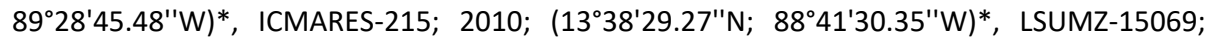
2011; (1328'27.4"N; 89¹0'54.2"W)*, LSUMZ-15077; 2011; (1340'10.1"N; 8945'27.9"W)*,

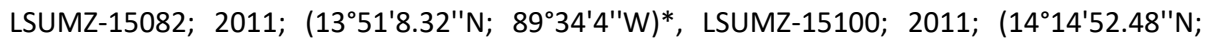
89²9'3"W)*, LSUMZ-15110; 2011; (14²2'8.76"N; 89¹2'45.4"W)*, LSUMZ-15112; 2011; $\left(14^{\circ} 10^{\prime} 46.56^{\prime \prime} \mathrm{N} ; 8^{\circ} 5^{\prime} 20.8^{\prime \prime} \mathrm{W}\right)^{*}$, LSUMZ-15117; 2011; (1353'4.74"N; 8857'48.1"W)*, LSUMZ-

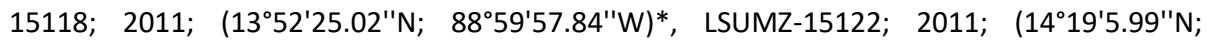
89³0'9.3"W)*, LSUMZ-15124; 2011; (1354'6.08"N; 8952'52.3"W)*, LSUMZ-15275; 2011;

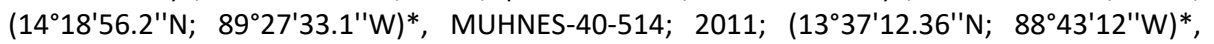

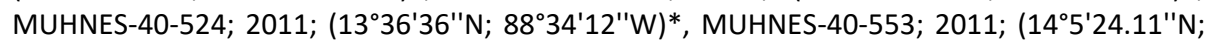
$\left.89^{\circ} 14^{\prime} 24^{\prime \prime W}\right)^{*}$, MUHNES-40-564; 2011; (14²1'36.07"N; 89³3'0"W)*, MUHNES-40-577; 2011;

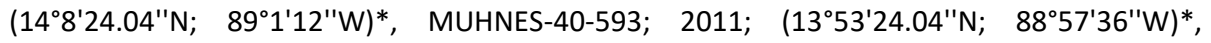

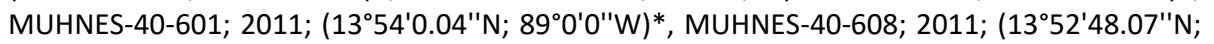

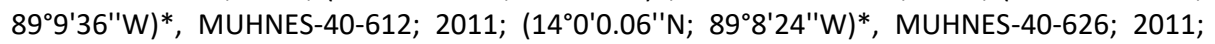
$\left(14^{\circ} 0^{\prime} 0.22^{\prime \prime} \mathrm{N} ; 88^{\circ} 39^{\prime} 36^{\prime \prime} \mathrm{W}\right)^{*}$, MUHNES-40-654; $2011 ;\left(13^{\circ} 45^{\prime} 0.06^{\prime \prime} \mathrm{N} ; 88^{\circ} 1^{\prime} 12^{\prime \prime} \mathrm{W}\right)^{*}$, MUHNES- 
40-662; 2011; $\left(13^{\circ} 52^{\prime} 48.22^{\prime \prime} \mathrm{N} ; \quad 88^{\circ} 14^{\prime} 24^{\prime \prime} \mathrm{W}\right)^{*}, \quad$ MUHNES-40-534; 2011; $\left(14^{\circ} 16^{\prime} 8.7^{\prime \prime} \mathrm{N}\right.$;

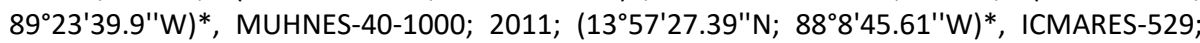

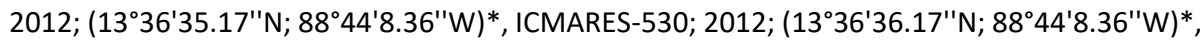
LSUMZ-17752; 2013; (1350'57.57"N; 89³3'25.08'"W).

Poeciliopsis $\quad$ FMNH-12094; 1924; $\left(13^{\circ} 24^{\prime} 31.26^{\prime \prime} \mathrm{N} ; 88^{\circ} 43^{\prime} 0.69^{\prime \prime} \mathrm{W}\right), \mathrm{FMNH}-12095 ; 1924 ;\left(13^{\circ} 24^{\prime} 31.26^{\prime \prime} \mathrm{N}\right.$;

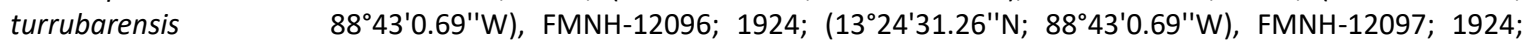
$\left(13^{\circ} 24^{\prime} 31.26^{\prime \prime} \mathrm{N} ; 88^{\circ} 43^{\prime} 0.68^{\prime \prime} \mathrm{W}\right)$, FMNH-12098; 1924; (13²4'31.26"N; $\left.88^{\circ} 43^{\prime} 0.68^{\prime \prime} \mathrm{W}\right), \mathrm{FMNH}-$ 12099; 1924; $\left(13^{\circ} 24^{\prime} 31.26^{\prime \prime} \mathrm{N} ; \quad 88^{\circ} 43^{\prime} 0.68^{\prime \prime} \mathrm{W}\right), \quad \mathrm{FMNH}-12100 ; 1924 ; \quad\left(13^{\circ} 46^{\prime} 38.5^{\prime \prime} \mathrm{N}\right.$; $\left.89^{\circ} 21^{\prime} 17.84^{\prime \prime} \mathrm{W}\right), \mathrm{FMNH}-12101 ; 1924 ;\left(13^{\circ} 46^{\prime} 38.56^{\prime \prime} \mathrm{N} ; 8^{\circ} 21^{\prime} 17.84^{\prime \prime} \mathrm{W}\right), \mathrm{FMNH}-12102 ; 1924$; $\left(13^{\circ} 46^{\prime} 38.54^{\prime \prime} \mathrm{N} ; 8^{\circ} 21^{\prime} 17.84^{\prime \prime W}\right), \mathrm{FMNH}-12103$; $1924 ;\left(13^{\circ} 46^{\prime} 38.6^{\prime \prime} \mathrm{N} ; 8^{\circ} 21^{\prime} 17.84^{\prime \prime} \mathrm{W}\right), \mathrm{FMNH}-$

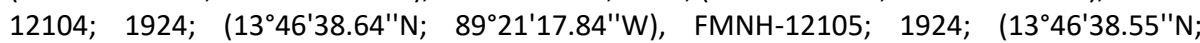
$\left.89^{\circ} 21^{\prime} 17.84^{\prime \prime W}\right), F M N H-12106 ; 1924 ;\left(13^{\circ} 46^{\prime} 38.63^{\prime \prime} \mathrm{N} ; 89^{\circ} 21^{\prime} 17.84^{\prime \prime} \mathrm{W}\right), \mathrm{FMNH}-12107 ; 1924 ;$

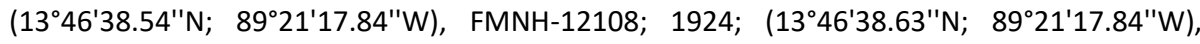
FMNH-12109; 1924; (1346'38.56"N; 89²1'17.84"W), FMNH-12110; 1924; (13\%46'38.61"N; $\left.89^{\circ} 21^{\prime} 17.84^{\prime \prime W}\right), F M N H-12111 ; 1924 ;\left(13^{\circ} 46^{\prime} 38.58^{\prime \prime N}\right.$; 89²1'17.84"W), USNM-87263; 1924; $\left(13^{\circ} 25^{\prime} 21.04^{\prime \prime} \mathrm{N} ; 8^{\circ} 41^{\prime} 58.2^{\prime \prime} \mathrm{W}\right)$, USNM-87263.5028; 1924; $\left(13^{\circ} 24^{\prime} 31.26^{\prime \prime} \mathrm{N} ; 88^{\circ} 43^{\prime} 0.68^{\prime \prime} \mathrm{W}\right)$, USNM-87264; 1924; $\left(13^{\circ} 25^{\prime} 23.52^{\prime \prime N} ; \quad 88^{\circ} 41^{\prime} 58.2^{\prime \prime W}\right), \quad$ USNM-87264.5028; 1924;

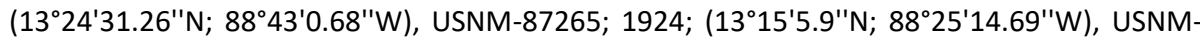
87265.5028; 1924; (1324'31.26"N; 8843'0.69"W), USNM-87266; 1924; $\left(13^{\circ} 15^{\prime} 47.52^{\prime \prime} \mathrm{N}\right.$;

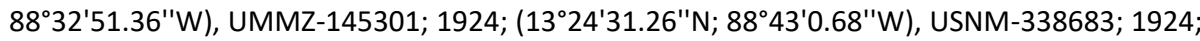
$\left(13^{\circ} 25^{\prime} 23.52^{\prime \prime} \mathrm{N} ; \quad 88^{\circ} 41^{\prime} 58.2^{\prime \prime} \mathrm{W}\right), \quad$ USNM-338683.524099999; $1924 ; \quad\left(13^{\circ} 24^{\prime} 31.26^{\prime \prime} \mathrm{N}\right.$; $\left.88^{\circ} 43^{\prime} 0.68^{\prime \prime} \mathrm{W}\right), \mathrm{TU}-202701 ; 1962 ;\left(13^{\circ} 21^{\prime} 32.7^{\prime \prime} \mathrm{N} ; 87^{\circ} 54^{\prime} 47.95^{\prime \prime} \mathrm{W}\right)^{*}, \mathrm{FMNH}-128123 ; 1975$;

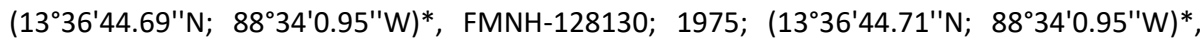

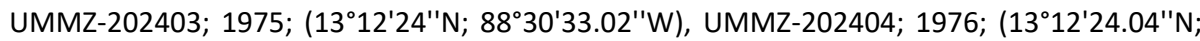

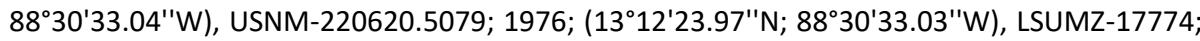

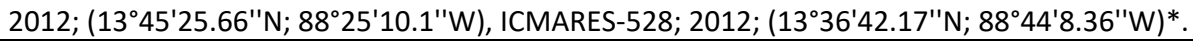

Profundulus guatemalensis

Profundulus kreiseri

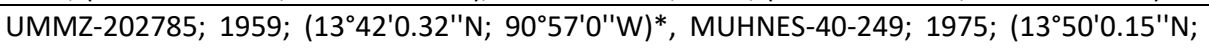
8956'32.09"W)*, MUHNES-40-174; 1979; (13\%49'44.9"N; 8957'50.13"W)*, LSUMZ-17761;

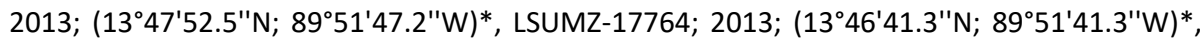
USNM-87231; 1924; (140'15.57"N; 89³2'14.63"W).

MUHNES-40-575; 2011; $\left(14^{\circ} 24^{\prime} 36.04^{\prime \prime N} \text {; } 89^{\circ} 26^{\prime} 24^{\prime \prime} \mathrm{W}\right)^{*}, \quad$ MUHNES-40-574; 2011; $\left(14^{\circ} 24^{\prime} 43.7^{\prime \prime} \mathrm{N} ; 8^{\circ} 26^{\prime} 7.61^{\prime \prime} \mathrm{W}\right)^{*}$, MUHNES-40-1002; 2011; (135' $\left.36^{\prime \prime} \mathrm{N} ; 8^{\circ} 9^{\prime} 0^{\prime \prime} \mathrm{W}\right)^{*}$, MUHNES-

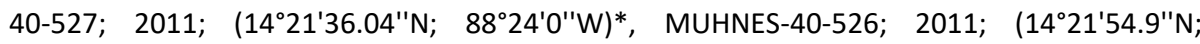
89²3'50.07"W)*, MUHNES-40-545; 2011; (14²18'12.1"N; 899'38.4"W)*, MUHNES-40-546; 2011; $\quad\left(14^{\circ} 18^{\prime} 14.71^{\prime \prime} \mathrm{N} ; \quad 89^{\circ} 9^{\prime} 35.29^{\prime \prime} \mathrm{W}\right)^{*}$, MUHNES-40-573; 2011; $\left(14^{\circ} 24^{\prime} 43.47^{\prime \prime} \mathrm{N}\right.$; 89²6'5.34"W)*, MUHNES-40-583; 2011; (14¹1'57.5"N; 890'4.6"W)*, LSUMZ-15105; 2011; $\left(14^{\circ} 21^{\prime} 39.3^{\prime \prime} \mathrm{N}\right.$; 89²4'11.3"W)*, LSUMZ-15106; 2011; (14¹9'30.7"N; 89³3'8.7"W), LSUMZ15108; 2011; $\left(14^{\circ} 21^{\prime} 48^{\prime \prime} \mathrm{N} ; 8^{\circ} 17^{\prime} 33.1^{\prime \prime} \mathrm{W}\right)^{*}$, MUHNES-40-1002; 2017; $\left(13^{\circ} 58^{\prime} 24.2^{\prime \prime} \mathrm{N}\right.$;

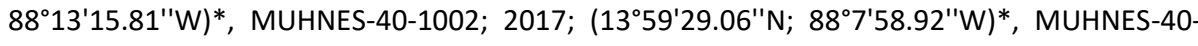
$1002 ; 2017 ;\left(13^{\circ} 54^{\prime} 7.87^{\prime \prime} \mathrm{N} ; 88^{\circ} 11^{\prime} 35.29^{\prime \prime} \mathrm{W}\right)$.

Pseudoxiphophorus anzuetoi

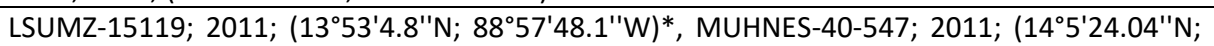

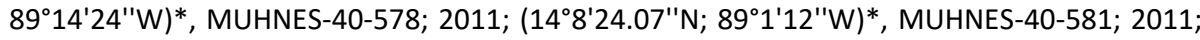
$\left(14^{\circ} 8^{\prime} 24^{\prime \prime} \mathrm{N} ; 8^{\circ} 1^{\prime} 12^{\prime \prime} \mathrm{W}\right)^{*}$, MUHNES-40-582; 2011; (140'0.07"N; 898'24"W)*, MUHNES-40-

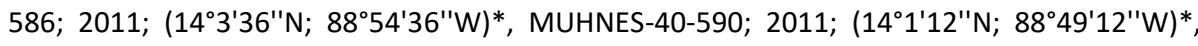

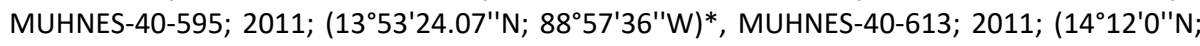
$\left.89^{\circ} 0^{\prime} 0^{\prime \prime} \mathrm{W}\right)^{*}$.

Edited by Melissa Garro Garita. 